\title{
Ozone production from the interaction of wildfire and biogenic emissions: a case study in Russia during spring 2006
}

\author{
E. Bossioli ${ }^{1}$, M. Tombrou ${ }^{1}$, A. Karali ${ }^{2}$, A. Dandou ${ }^{1}$, D. Paronis ${ }^{3}$, and M. Sofiev ${ }^{4}$ \\ ${ }^{1}$ Division of Environmental Physics and Meteorology, Department of Physics, National and Kapodistrian University of \\ Athens, Building PHYS-5, Panepistimioupolis, 15784 Athens, Greece \\ ${ }^{2}$ Institute for Environmental Research and Sustainable Development, National Observatory of Athens, I. Metaxa \& V. Pavlou, \\ P. Penteli (Lofos Koufou) 15236, Athens, Greece \\ ${ }^{3}$ Institute for Space Applications and Remote Sensing, National Observatory of Athens, I. Metaxa \& V. Pavlou, P. Penteli \\ (Lofos Koufou) 15236, Athens, Greece \\ ${ }^{4}$ Finnish Meteorological Institute, Erik Palmenin aukio 1, P.O. Box 503, 00101 Helsinki, Finland
}

Correspondence to: E. Bossioli (ebossiol@phys.uoa.gr)

Received: 7 November 2011 - Published in Atmos. Chem. Phys. Discuss.: 31 January 2012

Revised: 3 July 2012 - Accepted: 22 August 201 - Published: 6 September 2012

\begin{abstract}
The objective of this study is to investigate the contribution of biomass burning emissions to $\mathrm{O}_{3}$ production during small-scale dry-grass fires over Western Russia (24 April-10 May 2006) as well as to quantify the effect of biogenic emissions in this environment. By using the Factor Separation methodology, we evaluate the pure contribution of each one of these two sources and we appoint the significance of their synergistic effect on $\mathrm{O}_{3}$ production. The total (actual) contribution of each source is also estimated. Sensitivity simulations assess the effect of various fire emission parameters, such as chemical composition, emissions magnitude and injection height. The model results are compared with $\mathrm{O}_{3}$ and isoprene observations from 117 and 9 stations of the EMEP network, respectively.

Model computations show that the fire episode determines the sensitivity of $\mathrm{O}_{3}$ chemistry in the area. The reference run which represents grass fires with high $\mathrm{NO}_{\mathrm{x}} / \mathrm{CO}$ emission ratio (0.06) is characterized by VOC-sensitive $\mathrm{O}_{3}$ production. In that case, the pure impact of fire emissions on surface $\mathrm{O}_{3}$ is up to $40-45 \mathrm{ppb}$, while their synergistic effect with the biogenic emissions is proven significant (up to $8 \mathrm{ppb}$ ). Under a lower $\mathrm{NO}_{\mathrm{x}} / \mathrm{CO}$ molar ratio $(0.025$, representative of agricultural residues), the area is characterized by $\mathrm{NO}_{\mathrm{x}}$-sensitive chemistry and the maximum surface $\mathrm{O}_{3}$ predictions are almost doubled due to higher $\mathrm{O}_{3}$ production at the fire spots and lower fires' $\mathrm{NO}$ emissions.
\end{abstract}

\section{Introduction}

Vegetation fires release large amount of aerosols and trace gases, in particular, carbon dioxide $\left(\mathrm{CO}_{2}\right)$, carbon monoxide $(\mathrm{CO})$, nitrogen oxides $\left(\mathrm{NO}_{\mathrm{x}}\right)$, ammonia $\left(\mathrm{NH}_{3}\right)$, particulate matter (PM) and volatile organic compounds (VOC) into the atmosphere (Andreae and Merlet, 2001). The transformations of these primary tracers are significant in young plumes, as they substantially alter the plume composition before the smoke is diluted in the regional haze, therefore, can significantly alter the chemical state of the lower troposphere (Jost et al., 2003; Alvarado et al., 2010). In case of photochemical $\mathrm{O}_{3}$ production, this takes place within a few tens of minutes after the release (Goode et al., 2000; Jost et al., 2003; Yokelson et al., 2003), while it can also be detected several days later in the downwind plumes (Wotawa and Trainer, 2000; Forster et al., 2001; Real et al., 2007; Nassar et al., 2009). In their critical review paper, Jaffe and Wigder (2012) focus on the influence of wildfire emissions and of photochemistry on $\mathrm{O}_{3}$ production. The net $\mathrm{O}_{3}$ production rate in such plumes has been estimated of the order of $20-25 \mathrm{ppbh}^{-1}$ (Jost et al., 2003; Trentmann et al., 2003). Far downwind of large fire events enhanced $\mathrm{O}_{3}$ concentrations (e.g. up to $30 \mathrm{ppb}$ ) have been reported (McKeen, 2002; Fu et al., 2011; Kogan et al., 2011). Studies in the USA suggest that intense wildfire periods can significantly increase the frequency of $\mathrm{O}_{3}$ standards exceedances (Jaffe et al., 2008; Pfister et al., 2008). 
Furthermore, these pollution events may become more intense and frequent as the climate warms up (Westerling et al., 2006; Jaffe et al., 2008; Carvalho et al., 2011).

The identification of the $\mathrm{O}_{3}$ episodes related to biomass burning events and their likely source is mainly achieved by ground-based, aircraft, satellite observations, and trajectory calculations (Chung, 1984; Cheng et al., 1998; Damoah et al., 2004; Pfister et al., 2008; Alvarado et al., 2010; Bytnerowicz et al., 2010; Oltmans et al., 2010; Singh et al., 2010). The quantification of the fire effects on photochemical oxidants on regional scale is performed with photochemical trajectory models (Ladstätter-Weißenmayer et al., 2005; Real et al., 2007; Alvarado and Prinn, 2009) and chemical transport models (Marufu et al., 2000; Phadnis and Carmichael, 2000; McKeen, 2002; Junquera et al., 2005; Pfister et al., 2008; Alvarado et al., 2010; Fu et al., 2011; Huang et al., 2011; Konovalov et al., 2011). Despite the enhanced photochemistry that characterizes the fire events, comprehensive model estimates exist mainly for the transport process. Most of these studies have been performed for America. Only recently, more attention has been given on the sensitivity of the $\mathrm{O}_{3}$ production on wildfire emission inventories (Fu et al. 2011; Huang et al., 2011; Konovalov et al., 2011), fire emissions characteristics such as $\mathrm{NO}_{\mathrm{x}} / \mathrm{CO}$ emission ratio and inclusion of VOC (McKeen et al., 2002), and photochemistry (Junquera et al., 2005; Verma et al., 2009; Konovalov et al., 2011; Hodnebrog et al., 2012; Jaffe and Wigder, 2012). Most studies over Europe investigate the physicochemical properties of aerosols (e.g. Hodzic et al., 2006; Saarikoski et al., 2007; Miranda et al., 2009; Sofiev et al., 2009; Ulevicious et al., 2010) and only recently focus on $\mathrm{O}_{3}$ simulations (Verma et al., 2009; Carvalho et al., 2011; Girgždienė and Byčenkienè, 2011; Konovalov et al., 2011; Hodnebrog et al., 2012).

This study aims at contribute to our wider understanding of $\mathrm{O}_{3}$ production during a wild-land fire event. In particular, the objective of this paper is to investigate the contribution of biomass burning emissions to $\mathrm{O}_{3}$ production as well as to quantify the effect of biogenic emissions in this environment. By using the Factor Separation (FS) methodology (Stein and Alpert, 1993), we quantify the pure contribution of each one of these two sources as well as their synergistic effect on $\mathrm{O}_{3}$ production. We also estimate the total or "actual" contribution of the two source categories according to Tao et al. (2005). We demonstrate how a biomass burning event can alter the $\mathrm{O}_{3}-\mathrm{NO}_{\mathrm{x}}-\mathrm{VOC}$ sensitivity in the fires dominated area and how this effect depends on the burning material and its chemical properties. We also evaluate the impact of fire emissions characteristics, such as chemical composition, magnitude and injection height on $\mathrm{O}_{3}$ production.

The case study is the widespread wild-land fires over Western Russia during the spring of 2006. This biomass smoke episode was exceptionally long, lasting about 12 days (24 April-10 May 2006) (Saarikoski et al., 2007; Stohl et al., 2007; Treffeisen et al., 2007) and was mainly created by numerous small-scale dry-grass fires, largely man-made, that occurred under quite typical late-spring conditions (Sofiev et al., 2009). In particular, during this wild-land fire event, high temperatures (close to or above $20^{\circ} \mathrm{C}$ ) prevailed over most of Eastern Europe and Western Russia. A long-lasting anticyclonic system over Western Russia favored fairly low wind speeds limiting the dilution of anthropogenic pollutants over Central and Eastern Europe. During the first days (24 April1 May), severe degradation of air quality was registered in Finland where the smoke had been transported (Saarikoski et al., 2007). At the beginning of May (2-8 May), the pollution cloud moved towards the west leading to strong deterioration of air quality in most areas of Central and Northern Europe up to Iceland (Stohl et al., 2007). In this paper we focus on the episode that affected Central Europe (2-8 May).

Our study complements previous modeling studies, which assessed the impact of biomass burning on aerosols during this fire event (Saarikoski et al., 2007; Stohl et al., 2007; Treffeisen et al., 2007) and on air pollution levels in the European Arctic (Stohl et al., 2007) but also the findings of studies focusing on other types of fires in the area such as boreal (e.g. Verma et al., 2009) and peat fires (e.g. Konovalov et al., 2011).

The MM5/CAMx modeling system is used for numerical simulations. The fire emissions were generated by the FMI Fire Assimilation System (FAS) based on MODIS Fire Radiative Power (FRP) product (Sofiev et al., 2009). Biogenic emissions include volatile organic compounds (BVOC) from forests, shrubs and crops, as well as NO emissions from agricultural areas. These are estimated with the global Model of Emissions of Gases and Aerosols from Nature (MEGAN) (Guenther et al., 2006).

\section{Methodology, modeling tool, and input data}

The collection of the model simulations of this study includes the reference run and a series of additional runs in order to apply the FS technique. The FS technique resolves the contribution from a single factor alone (pure), but also can determine any interactions between that factor and others (synergistic effect), by using a linear combination of a series of simulations. In our study, two factors are considered, fire and biogenic emissions.

Following the FS technique, four simulations have been performed. Their assumptions and the definitions of the various contribution components are presented in Table 1 . The simulations results are denoted by $f$. The variables $f_{\mathrm{F}}^{\prime}$ and $f_{\mathrm{B}}^{\prime}$ denote the pure contributions from fires and biogenic source categories, respectively. The variable $f_{\mathrm{BF}}^{\prime}$ represents the contribution due to the interaction of the two sources, while $f_{0}^{\prime}$ is the $\mathrm{O}_{3}$ unrelated to either fire or biogenic emissions.. The total or "actual" contribution of the two source categories is also examined as discussed in Tao et al. (2005). For a source category, this is defined as the difference between the simulation results obtained with all source categories included 
Table 1. Summary of different model runs performed for the application of the FS technique and definitions of the various contribution components.

\begin{tabular}{lll}
\hline Simulation & Simulation results & Emissions \\
\hline Reference & $f_{\mathrm{BF}}$ & $\begin{array}{l}\text { Anthropogenic, biogenic, fires } \\
\text { Anthropogenic, biogenic }\end{array}$ \\
NOFIRES & $f_{\mathrm{B}}$ & $\begin{array}{l}\text { Anthropogenic, fires } \\
\text { Anthropogenic }\end{array}$ \\
NOFIRES+NOBIOG & $f_{\mathrm{F}}$ & \\
\hline Contributions & $f_{0}$ & \\
\hline$f_{\mathrm{BF}}-f_{\mathrm{F}}$ & & \\
$f_{\mathrm{BF}}-f_{\mathrm{B}}$ & Total contribution of biogenic emissions \\
$f^{\prime}{ }_{0}=f_{0}$ & Total contribution of fire emissions \\
$f^{\prime} \mathrm{B}=f_{\mathrm{B}}-f_{0}$ & O 3 unrelated to either biogenic or fire emissions \\
$f^{\prime} \mathrm{F}=f_{\mathrm{F}}-f_{0}$ & Pure contribution of biogenic emissions \\
$f^{\prime}{ }_{\mathrm{BF}}=f_{\mathrm{BF}}-\left(f_{\mathrm{B}}+f_{\mathrm{F}}\right)+f_{0}$ & Synergistic effect due to fires and biogenic emissions & \\
\hline
\end{tabular}

$\left(f_{\mathrm{BF}}\right)$ and those with all but this particular source $\left(f_{\mathrm{B}}\right.$ or $\left.f_{\mathrm{F}}\right)$. In all runs the anthropogenic source is taken into account as background.

Finally, additional sensitivity simulations, using different emission setups, focus on the fire emission parameters, such as chemical composition (AGRIC), emissions magnitude (EMISS0.8) and injection height (F1, F2). The assumptions of these simulations along with their results are presented in Sect. 3.4.

\subsection{Atmospheric chemistry-transport models}

CAMx (Environ, 2004) is an Eulerian photochemical dispersion model that simulates the dispersion, chemical reaction, and removal of pollutants for both gaseous and particulate phase, in the troposphere by solving the pollutant continuity equation. CAMx model was applied in LATLON projection. The study area covers Europe $\left(32.9^{\circ}-71.9^{\circ} \mathrm{N} ;-12.2^{\circ} \mathrm{W}-\right.$ $\left.41.8^{\circ} \mathrm{E}\right)$ with spatial resolution $0.4^{\circ} \times 0.2^{\circ}(135 \times 195$ cells $)$. The initial and boundary conditions are temporally and spatially constant concentrations based on climatological data (Tarasova et al., 2007). In this study, we focus on the gas phase chemistry results simulated with CB-IV chemical mechanism (Gery et al., 1989). This mechanism includes an explicit oxidation mechanism for isoprene, while the terpenes are examined through the chemistry of olefins, aldehydes and parafins carbon groups. The TUV radiative transfer and photolysis model (Madronich, 1993, 2000) is used as a CAMx pre-processor to provide the model with a multi-dimensional lookup table of photolytic rates by surface albedo, altitude, zenith angle, haze turbidity, and total $\mathrm{O}_{3}$ column. Total $\mathrm{O}_{3}$ column from OMI measurements for each day of the simulation period have been used. The aerosol impact on photolysis rates has not been taken into account although the "obscuring" effect of aerosols (Tzanis et al., 2009; Konovalov et al., 2011) may decrease the $\mathrm{O}_{3}$ production at the surface by up to $20 \%$ (Jaffe and Wigder, 2012). Photolysis rates have been adjusted for the presence of clouds using the approach developed for the Regional Acid Deposition Model (Chang et al., 1987).

The meteorological input data are provided by the PSU/NCAR MM5 meteorology non-hydrostatic model (Grell at al., 1994), Version 3-6-1. The model is applied in Lambert Conformal Space projection with a spatial resolution of $30 \mathrm{~km} \times 30 \mathrm{~km}(279 \times 178$ cells $)$. In the vertical, 22 non-uniform vertical $\sigma$-layers are used extending up to $14 \mathrm{~km}$ $(100 \mathrm{hPa})$. The resolution, up to the first $3 \mathrm{~km}$, was designated in order to better simulate the effect of fire emissions; the lowest $\sigma$-level (mid-point) is at about $14 \mathrm{~m}$ above ground level while nine vertical levels exist up to $3 \mathrm{~km}$ (every $100 \mathrm{~m}$ up to $0.5 \mathrm{~km}$, every $500 \mathrm{~m}$ up to $3 \mathrm{~km}$ ). CAMx follows the same vertical resolution.

The initial and lateral boundary conditions are provided by the National Centre for Atmospheric Prediction (NCEP) Final Analyses $(\mathrm{FNL})$ data $\left(1^{\circ} \times 1^{\circ}\right)$, every $6 \mathrm{~h}$, and the $25-$ category USGS land-use classification scheme is adopted, in order to provide land-cover data for the model domain. For the present study, the applied physics parameterizations are: the Medium-Range Forecast (MRF) PBL scheme (Hong and Pan, 1996), the Grell cumulus scheme (Grell, 1993), the Schultz micro-physics scheme (Schultz, 1995), the CloudRadiation scheme (Dudhia, 1989), and the Noah Land Surface Model (Chen and Dudhia, 2001). All the meteorological data, necessary for CAMx simulations, were regridded on the $0.4^{\circ} \times 0.2^{\circ}$ CAMx grid by applying the mm5camxv4.3 preprocessor.

EMEP anthropogenic emissions of $\mathrm{NO}_{\mathrm{x}}, \mathrm{SO}_{\mathrm{x}}$, nonmethane VOC (NMVOC), $\mathrm{CO}, \mathrm{NH}_{3}$ have been used covering 11 SNAP categories plus emissions from ships and volcanoes $\left(\mathrm{SO}_{\mathrm{x}}\right)$, for the reference year 2004. The speciation of the anthropogenic NMVOC for each SNAP category is based on Passant (2002). The simulations cover the period from 24 April to 10 May 2006 with two days spin-up. 

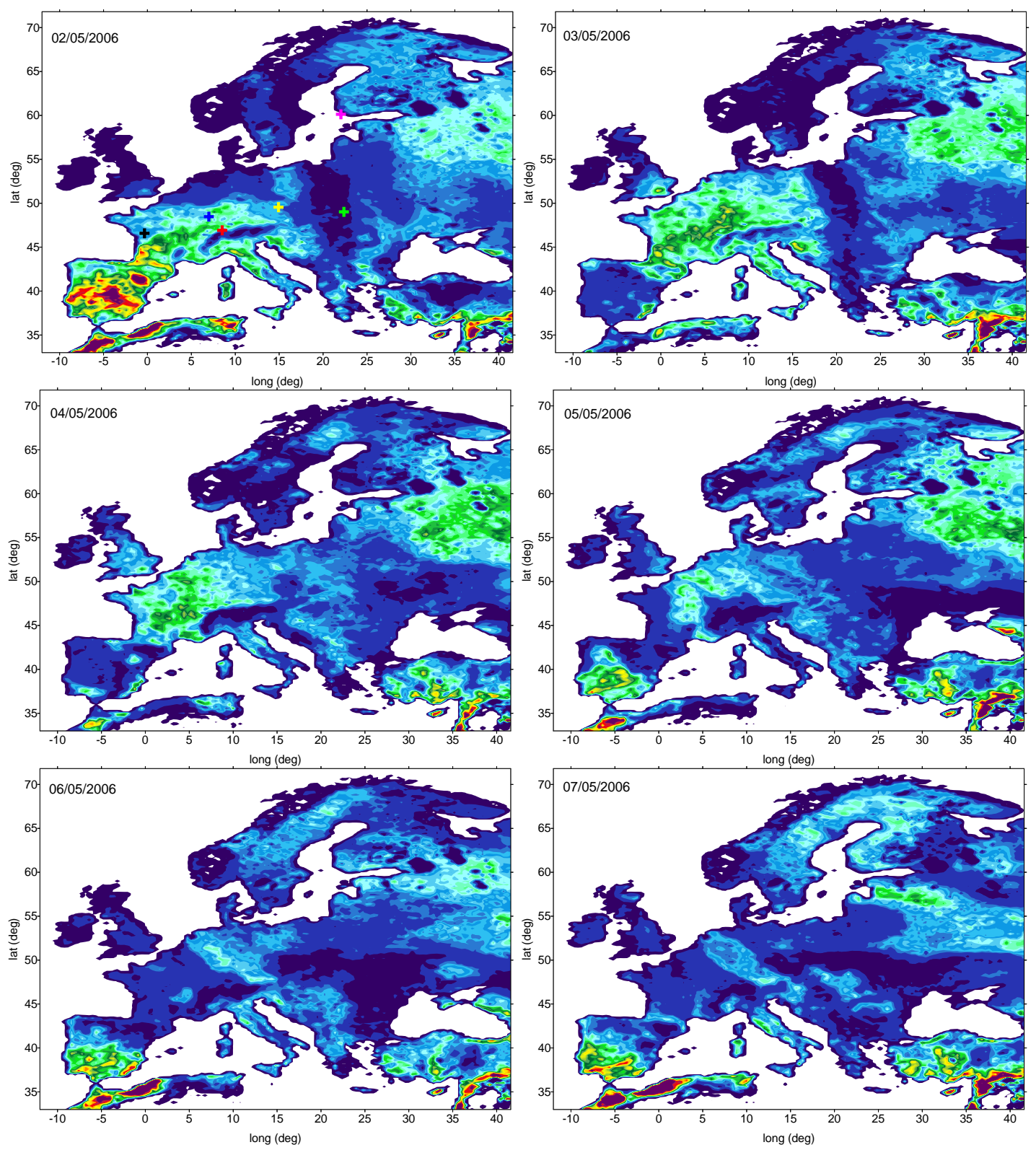

웃 L L

Fig. 1. Daily BVOC emission rates $\left(\mathrm{mg} \mathrm{m}^{-2}\right.$ day $^{-1}$ ) estimated with MEGAN for 2 to 7 May 2006. The symbols in the first plot correspond to monitoring stations measuring isoprene (red: CH0005R; black: FR0015R; blue: FR0008R; yellow: CZ0003R; magenta: FI0009R; green: SK0006R).

\subsection{Biogenic emissions}

Biogenic emissions have been estimated for each hour of the examined period and implemented in the model setup. The net emission rate of each trace gas compound $\left(\mathrm{mg} \mathrm{m}^{-2} \mathrm{~h}^{-1}\right)$ was calculated from landcover and weather data, by applying the MEGAN algorithm (Guenther et al., 2006). In particular, monthly average Leaf Area Index (LAI) and standard emis- sion factors were taken from the National Center of Atmospheric Research (NCAR) at a base resolution of $30 \mathrm{~s} \times 30 \mathrm{~s}$ and with reference year 2003 and 2000, respectively. In this study, we considered the weighted average of five plant functional types (broadleaf trees, needle trees, crops, shrubs and grass) as the standard emission factors. Prior to their use, the landcover data were regridded on the required spatial resolution, $0.4^{\circ} \times 0.2^{\circ}$. The necessary meteorological data, 
namely the fields of hourly surface temperature and solar radiation were provided by MM5 simulations and regridded with $\mathrm{mm} 5$ camx pre-processor. Thereafter, the hourly spatial distribution of isoprene, terpenes, biogenic oxygenated volatile organic compounds (BOVOC) and NO emissions have been calculated. This study does not consider the impact (direct and indirect) of fires on isoprene and monoterpenes emissions (e.g. direct leaf wounding, photosynthetic inhibition) as was measured by Alessio et al. (2004).

In Fig. 1, the spatial distribution of the daily BVOC emission rates over Europe, for the period 2 to 7 May, is presented. The highest BVOC emissions are found over the Iberian Peninsula, Morocco, Tunisia, parts of Italy, France, Austria, Western Turkey and Russia, which is in agreement with recent studies (e.g. Simpson et al., 1999; Curci et al., 2009). In particular, Spain appears as the major hot spot for BVOC emissions, displaying daily values up to $10 \mathrm{mg} \mathrm{m}^{-2} \mathrm{day}^{-1}$. Despite its high emission potential, relatively low emissions are observed in Scandinavia (0.5$2 \mathrm{mg} \mathrm{m}^{-2}$ day $^{-1}$ ), mainly due to low solar radiation and surface temperature. Over Central Europe, UK and Western Russia, BVOC emissions reach up to $4.5 \mathrm{mg} \mathrm{m}^{-2} \mathrm{day}^{-1}$, depending on the prevailing atmospheric conditions.

The total BVOC and NO emissions over the modeling domain, for the whole simulated period, were estimated equal to 170.2 and $2.4 \mathrm{kt}$, respectively, with daily averages $11.35 \pm 0.99 \mathrm{kt}\left(17.35 \pm 1.54 \mathrm{~g} \mathrm{~m}^{-2}\right)$ and $0.16 \pm 0.02 \mathrm{kt}$ $\left(0.24 \pm 0.03 \mathrm{~g} \mathrm{~m}^{-2}\right)$, respectively. Among the BVOC, the larger fraction $43.4 \%$ is for isoprene, $17.4 \%$ for terpenes (analyzed in 39\% for a-pinene, $17 \%$ for b-pinene, $10 \%$ ocimene, $12 \%$ limonene, $11 \% 3$-carene and about $5 \%$ for myrcene and sabinene) and $39.1 \%$ for BOVOC (99\% methanol and $1 \%$ methyl butenol). It is difficult to compare directly our results with those from other studies, because different simulation periods were used. However, the calculated values of BVOC emissions in several hot spots in Europe are of the same magnitude with those from previous studies (Curci et al., 2009; Poupkou et al., 2010). The estimated terpenes are lower relative to isoprene emissions in this study. Apart from the different atmospheric conditions, this discrepancy could be attributed to high uncertainties in estimating terpenes emissions due to dissimilarities regarding (a) model approaches, (b) emission factors, (c) land use data, (d) biomass density or a combination of all these factors (Arneth et al., 2008; Steinbrecher et al., 2009).

In order to evaluate MEGAN estimations over the area, during the period of study, the simulated isoprene concentrations are compared to observations from stations of the EMEP network. Isoprene has been chosen for comparison since its chemistry is described explicitly by CB-IV mechanism. Unfortunately, the number of stations with available isoprene measurements is quite small (9) (http://www.nilu.no/projects/ccc/emepdata.html); one in Germany (DE0043R), three in France (FR0008R, FR0013R, FR0015R), two in Finland (FI0009R, FI0096R), one in the
Czech Republic (CZ0003R), one in Switzerland (CH0005R) and one in Slovakia (SK0006R). The sampling period was too coarse as canister samples were taken in most stations, while in CH0005R and DE0043R, a continuous Gas Chromatography monitor was operating, but with limited data (12\% and $8.6 \%$, respectively of the total simulation hours). Although the available data do not constitute the basis for a full scale evaluation, the comparison provides an indication of whether the model can predict the order of the observations magnitude. Based on the same database, Poupkou et al. (2010) evaluated hourly isoprene predictions by CAMx model in a study of BVOC estimations over Europe, while Zare et al. (2012) concluded that isoprene estimates using the MEGAN model had a better agreement with the mean observed values than the Global Emissions Inventory Activity (GEIA) inventory (Guenther et al., 1995).

The mean observed and mean simulated isoprene values in all but one stations agree within a factor up to 3 . The mean observed levels are underestimated at the French stations FR0008R and FR0013R and the Czech station, while they are overestimated at the rest of the stations. Significant discrepancies were found only for the DE0043R station (agreement within a factor of 8). In Fig. 2, time series of predicted and observed isoprene concentrations are presented at six stations: FR0015R, FR0008R, FI0009R, SK0006R, CH0005R, and CZ0003R. The comparison showed that at the CH0005 station, the diurnal cycle is reproduced with temporal correlation coefficient 0.366 . Overall, our results are in conjunction with the uncertainties reported in the literature for biogenic emissions estimates of a factor 3-5 (Simpson et al., 1999).

\subsection{Fire emissions}

The daily pattern of PM emission fluxes, generated by the FMI FAS system (Sofiev et al., 2009), is based on MODIS FRP product and the recalibrated methodology of Ichoku and Kaufman (2005). In particular, Sofiev et al. (2009) continued the work of Ichoku and Kaufman (2005) and provided estimations of total PM emission coefficients for each land type. They concluded to total PM emission coefficients of $0.1 \mathrm{~kg} \mathrm{MJ}^{-1}$ for forest, $0.05 \mathrm{~kg} \mathrm{MJ}^{-1}$ for grass lands, and an average of $0.075 \mathrm{~kg} \mathrm{MJ}^{-1}$ for mixed areas. The detailed discussion about FAS system is given in Sofiev et al. (2009).

The daily distribution of the total FRP release from each land-use class (mixed, forest, grass) revealed that the particular fire event, represents mainly a dry grass fire (Sofiev et al., 2009). The patterns of all gaseous emission fluxes follow the $\mathrm{PM}$ ones and are based on scaling factors relative to total PM considering grass as the burning material. However, in order to quantify the sensitivity of the $\mathrm{O}_{3}$ production on the fire emission properties a sensitivity run considering agricultural residues as burning material (AGRIC) is also examined. The scaling factors relative to total PM are taken from Andreae 

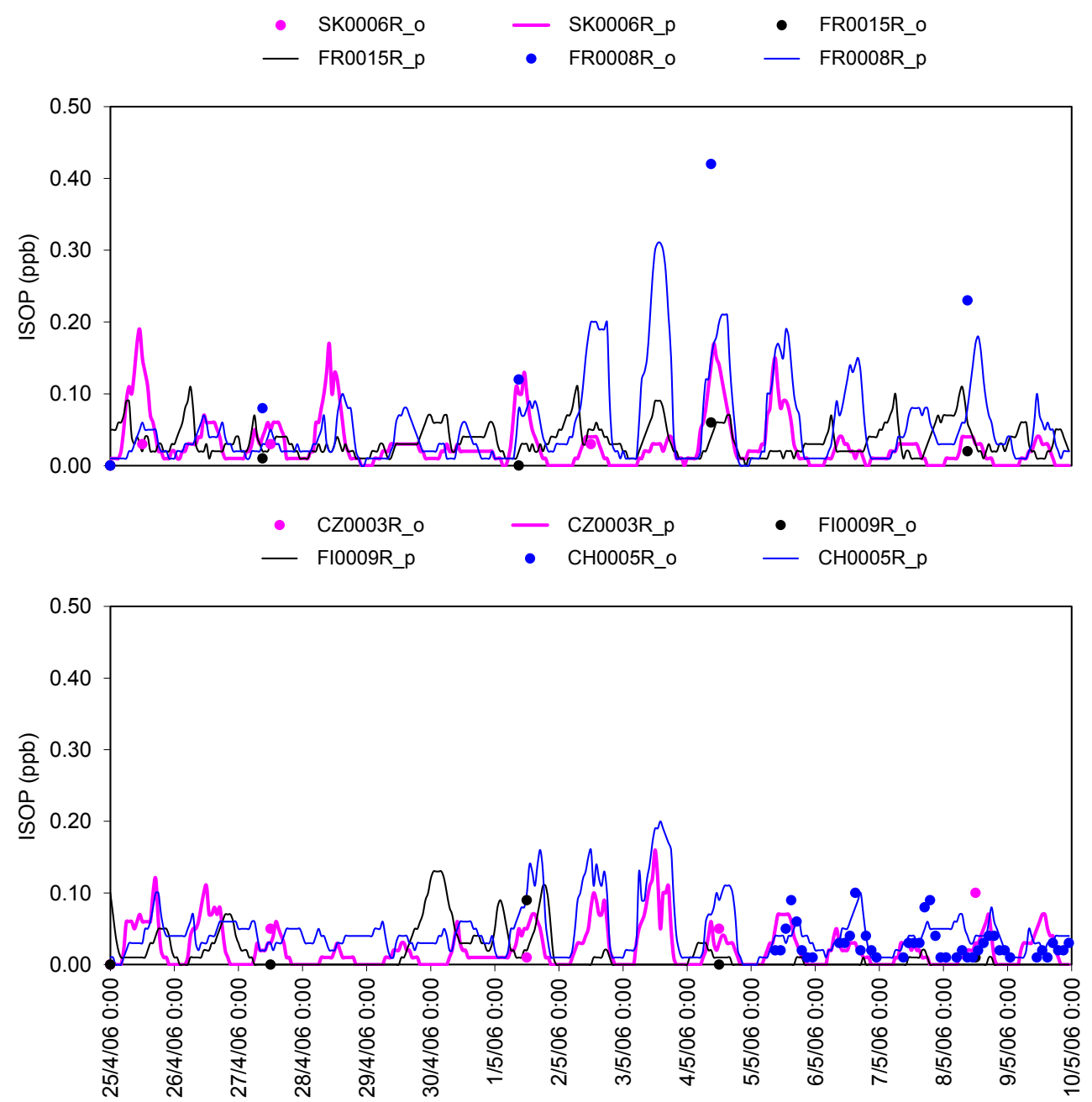

Fig. 2. Time series of predicted (lines) and observed (symbols) surface isoprene concentrations (ppb) during the simulation period at six stations of the EMEP network. The location of the stations is presented in Fig. 1 (upper left plot).

and Merlet (2001) for both surface fuels and are assumed to be spatially constant in each case.

For the grass case, the gaseous emission flux is estimated 8.9 times larger than the particulate mass flux and its composition is $88.3 \%$ of $\mathrm{CO}, 4.6 \%$ of NMVOC, $5.3 \%$ of $\mathrm{NO}_{\mathrm{x}}$, $1.4 \%$ of $\mathrm{NH}_{3}$, and $0.5 \%$ of $\mathrm{SO}_{2}$ (mass fractions). For the agricultural residues, the gaseous emission flux is 7.9 times larger than the particulate mass flux and is distributed in $89.1 \%$ of $\mathrm{CO}, 6.8 \%$ of NMVOC, $2.4 \%$ of $\mathrm{NO}_{\mathrm{x}}, 1.3 \%$ of $\mathrm{NH}_{3}$, and $0.4 \%$ of $\mathrm{SO}_{2}$ (mass fractions). Thus, the molar $\mathrm{NO}_{\mathrm{x}} / \mathrm{CO}$ ratios for the two burning materials are 0.06 for grassland and 0.025 for agricultural residues. The speciation of NMVOC is according to Andreae and Merlet (2001). In Fig. 3, the daily patterns of $\mathrm{NO}_{\mathrm{x}}$ emissions, originated from fires during the period 2 to $7 \mathrm{May}$, are presented for the reference run (grass). The vertical distribution of fire emissions is spatially constant up to $1000 \mathrm{~m} ; 20 \%$ uniformly distributed up to $100 \mathrm{~m}$ (two vertical layers), $30 \%$ uniformly distributed between 100 and $500 \mathrm{~m}$ (three vertical layers), and $50 \%$ uniformly distributed up to $1000 \mathrm{~m}$ (two vertical layers) (Sofiev et al., 2009). A normalization function is used for the hourly variation of the fire intensity which is considered fixed for all days; day-time emission intensity is $25 \%$ higher than the daily-mean level while the night-time emission intensity is $25 \%$ lower (Saarikoski et al., 2007).

For the examined period, the daily average $\mathrm{CO}, \mathrm{NO}_{\mathrm{x}}$, and NMVOC fire emissions injected in the modeling domain is $1102.4 \pm 611.9,66.6 \pm 36.9$ and $57.7 \pm 32.0 \mathrm{kt}$, respectively for the grass case and $996.3 \pm 552.9,27.0 \pm 15.0$ and $75.9 \pm 42.1 \mathrm{kt}$, respectively for the agricultural residues case. In Fig. 4, the daily $\mathrm{NO}_{\mathrm{x}}$ and NMVOC emissions from biomass burning for both burning materials are compared with the other emission sources modeled in this study over Europe. The strength of fire emissions during the episode exceeds the combined European anthropogenic and biogenic 

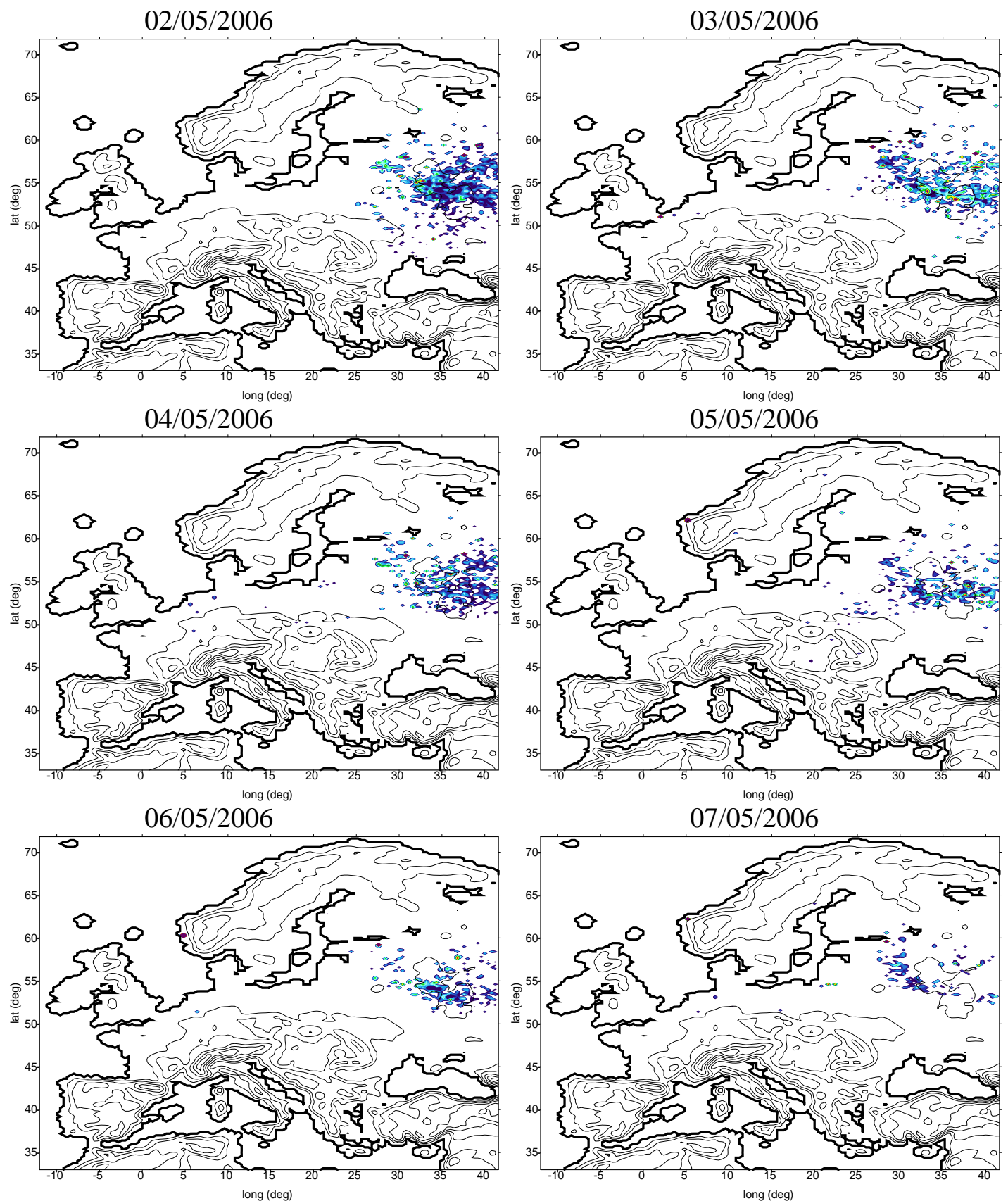

융 윰 운 웅 \&

Fig. 3. Daily patterns of $\mathrm{NO}_{\mathrm{x}}$ emissions (t), originated from fires (grass), during the period 2-7 May 2006.

emissions for $\mathrm{NO}_{\mathrm{x}}$ and NMVOC. The rates become comparable only during the last days of the episode.

\section{Results}

The presentation of the results is organized as follows: the episode analysis as simulated by the reference run is discussed in Sect. 3.1 and the evaluation of the $\mathrm{O}_{3}$ predictions is assessed in Sect. 3.2. The results of the FS method are analyzed. In particular, the pure, total and synergistic effect 

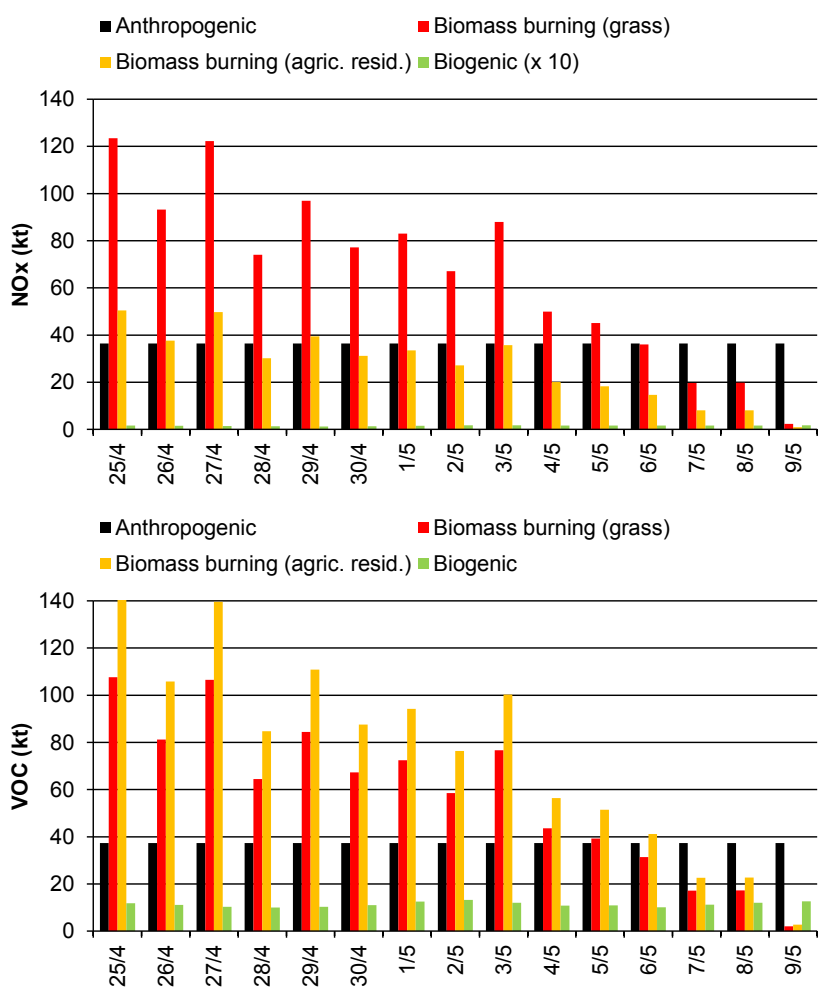

Fig. 4. Anthropogenic, biomass burning (grass and agricultural residues) and biogenic $\mathrm{NO}_{\mathrm{x}}$ and NMVOC emissions released over Europe during the simulation period.

of biomass burning and biogenic emission sources are presented in Sect. 3.3. Finally, the results of the sensitivity tests are analyzed and compared with the results of the reference run in Sect. 3.4.

\subsection{Reference run - Episode analysis}

The interpretation of the model results is discussed through the $\mathrm{O}_{3}-\mathrm{NO}_{\mathrm{x}}-\mathrm{VOC}$ sensitivity. In general, large $\mathrm{NO}_{\mathrm{x}}$ sources (e.g. urban areas or polluted remote areas) are characterized by low $\mathrm{VOC} / \mathrm{NO}_{\mathrm{x}}$ ratios and correspond to the VOCsensitive regime. In the VOC-sensitive regime, $\mathrm{O}_{3}$ increases with increasing VOC and decreases with increasing $\mathrm{NO}_{\mathrm{x}}$ (Sillman, 1999). By contrast, remote areas are usually characterized by low ambient $\mathrm{NO}_{\mathrm{x}}$ and high BVOC emission levels, thus by fairly high $\mathrm{VOC} / \mathrm{NO}_{\mathrm{x}}$ ratios and correspond to the $\mathrm{NO}_{\mathrm{x}}$-sensitive regime. In the $\mathrm{NO}_{\mathrm{x}}$-sensitive regime, $\mathrm{O}_{3}$ increases with increasing $\mathrm{NO}_{\mathrm{x}}$ and shows relatively little change in response to increased VOC. Beekmann and Vautard (2010) discussed the spatial distribution of the $\mathrm{NO}_{\mathrm{x}}-$ VOC sensitive regimes over Europe and their temporal variability. They concluded that the northwestern Europe lies in the VOC-sensitive regime while Mediterranean and Eastern Europe are in the $\mathrm{NO}_{\mathrm{x}}$-sensitive regime. Below, it is shown that the biomass burning can alter the $\mathrm{O}_{3}$ sensitivity over the wider area, which is influenced by the dispersion of fire plumes (Eastern Europe and Western Russia).

The spatial distribution of the simulated $\mathrm{VOC} / \mathrm{NO}_{\mathrm{x}}$ ratios is presented for the reference run for the period 2 7 May in Fig. 5. The $\mathrm{VOC} / \mathrm{NO}_{\mathrm{x}}$ ratio for each cell, is given at the hour when the peak $\mathrm{O}_{3}$ concentration occurred. All the results presented from hereafter will be referred at the same time, except otherwise specified. Until 3 May, the ratios over the fires dominated area range between 1 and $3 \mathrm{ppbC} \mathrm{ppb}^{-1}$, lower than those characterizing Central Europe $\left(4-15 \mathrm{ppbC} \mathrm{ppb}^{-1}\right)$. The fire event releases higher amount of $\mathrm{NO}_{\mathrm{x}}$ compared to VOCs, thus, low $\mathrm{VOC} / \mathrm{NO}_{\mathrm{x}}$ concentration ratios prevail over the area of interest. Under these conditions, the $\mathrm{O}_{3}$ production over the burnt areas is characterized as VOC-sensitive and is mainly controlled by the VOC-OH oxidation reactions. These findings are in agreement with the studies of Mason et al. (2001) and Trentmann et al. (2003), who also pointed out the VOC-sensitivity of the $\mathrm{O}_{3}$ production in biomass burning plumes. Under normal conditions over Scandinavia, relatively high BVOC emissions and almost negligible impact of fire $\mathrm{NO}_{\mathrm{x}}$ emissions usually result in high $\mathrm{VOC} / \mathrm{NO}_{\mathrm{x}}$ ratios $\left(\sim 55 \mathrm{ppbC} \mathrm{ppb}^{-1}\right)$.

The chemistry leading to $\mathrm{O}_{3}$ production is initiated by reactions of hydroxyl $(\mathrm{OH})$ radicals with $\mathrm{CO}$ and VOC. These reactions produce peroxy radicals $\left(\mathrm{HO}_{2}, \mathrm{RO}_{2}\right)$ which then convert $\mathrm{NO}$ to $\mathrm{NO}_{2}$ leading to $\mathrm{O}_{3}$ formation. In Fig. 6, the integrated hourly oxidation rates of $\mathrm{VOC}-\mathrm{OH}$ reactions (total, anthropogenic and natural VOC, including $\mathrm{C}_{1}$ components, $\mathrm{CO}$ and $\mathrm{CH}_{4}$ ) are presented for 2-7 May, at the hour of peak $\mathrm{O}_{3}$ concentration. During all days, the fire spots exhibit the highest VOC-OH oxidation rates, up to $30 \mathrm{ppbh}^{-1}$ (during 25-27 April up to $50 \mathrm{ppb} \mathrm{h}^{-1}$, not shown). Accordingly, $\mathrm{O}_{3}$ production rates (determined as the rate at which peroxy radicals react with $\mathrm{NO}$ ) reach up to $60 \mathrm{ppb} \mathrm{h}^{-1}$ and at the same time $\mathrm{O}_{3}$ is highly depleted, due to its reaction with the emitted $\mathrm{NO}$, leading to low surface $\mathrm{O}_{3}$ concentrations, as was also pointed out by Trentmann et al. (2003). The predicted maximum hourly $\mathrm{O}_{3}$ concentrations are presented as color shades for each day of the period 2-7 May, in Fig. 7. The observed maximum hourly concentrations at 117 rural background monitoring EMEP stations (http://www.emep.int) are also shown in the same plots. It is evident from Fig. 7 that close to the fire spots, low $\mathrm{O}_{3}$ concentrations, up to $30 \mathrm{ppb}$, are predicted.

According to model predictions, the oxidation capacity of the atmosphere is not adequate to produce $\mathrm{O}_{3}$ excess before 3 May. After that date, the increase of water vapor over Central and Northern Europe and Western Russia contributes to higher "new" $\mathrm{OH}$ radical concentrations initiated by $\mathrm{O}_{3}$ photolysis (Fig. 6). The oxidation capacity over the eastern part of the domain (Eastern Europe and Western Russia) is further enhanced due to the increased biogenic activity (Fig. 1). In particular, the BVOC oxidation produces secondary carbonyl species, whose photolysis provides additional radicals. 


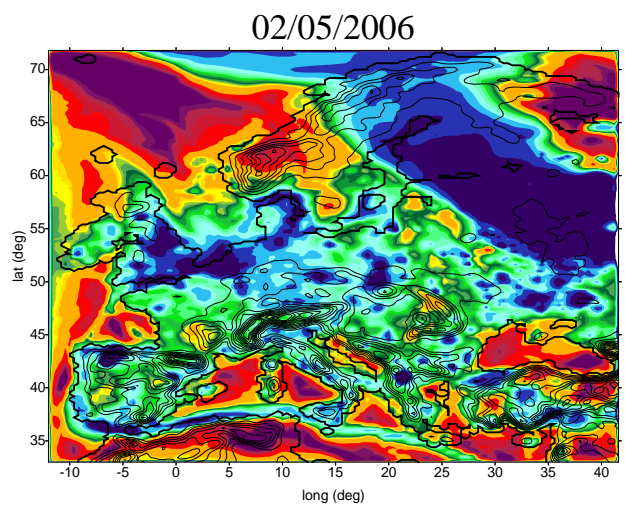

04/05/2006

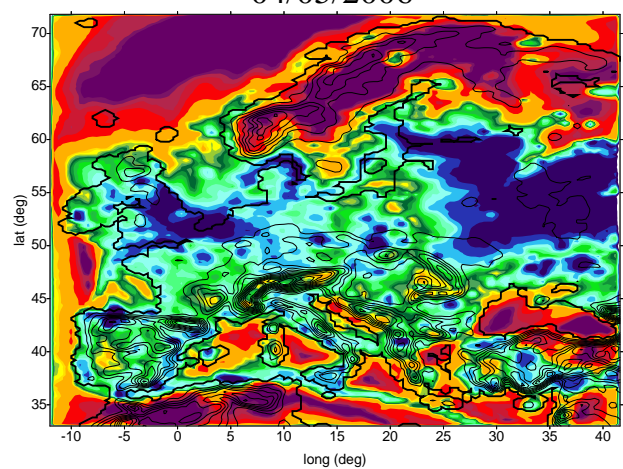

06/05/2006

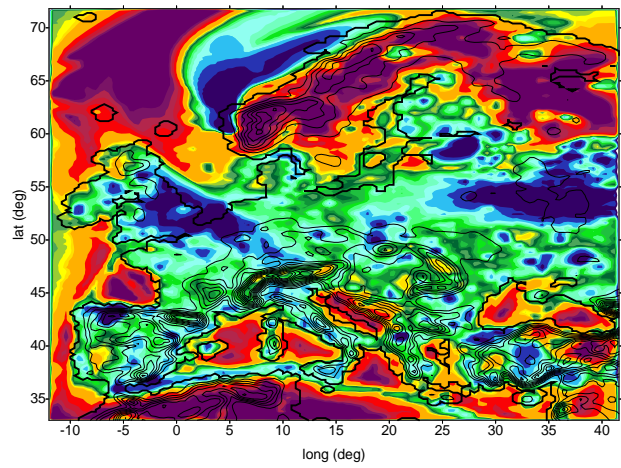

03/05/2006

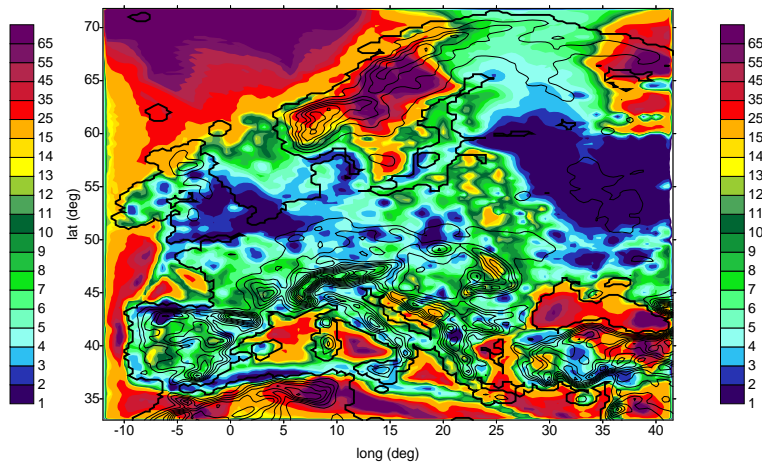

05/05/2006

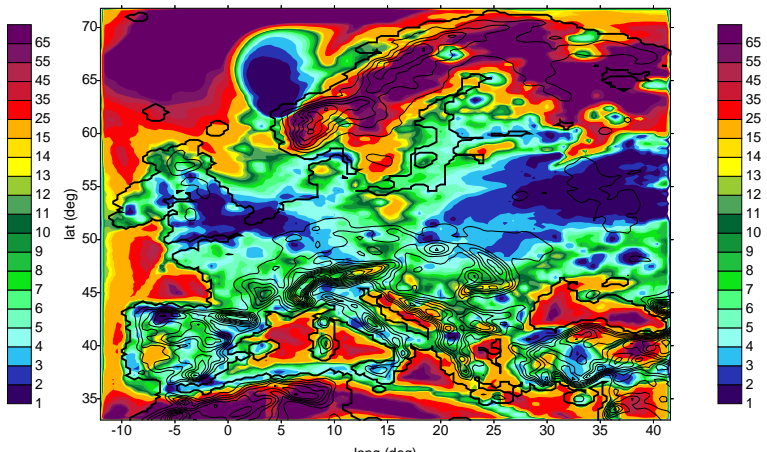

$07 / 05 / 2006$

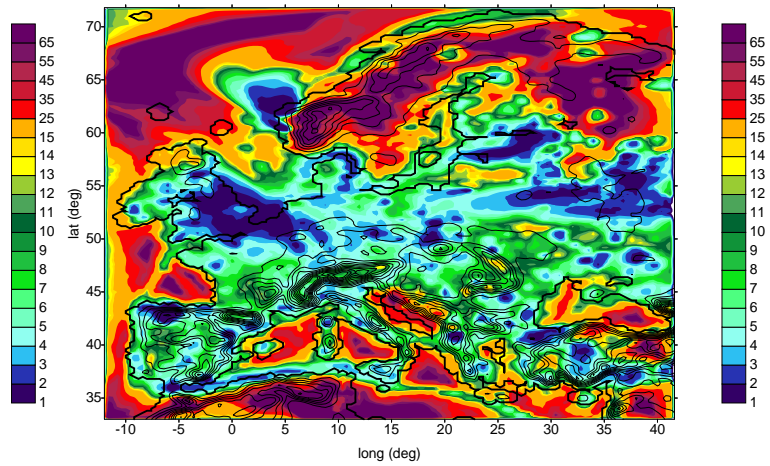

Fig. 5. Simulated $\mathrm{VOC} / \mathrm{NO}_{\mathrm{x}}$ ratio for each cell $\left(\mathrm{ppb} \mathrm{Cppb}^{-1}\right)$, at the hour when the peak $\mathrm{O}_{3}$ concentration occurred during the period 2-7 May 2006.

Eventually, the admixture of reactive BVOC emissions combined with the decrease of the fire $\mathrm{NO}_{\mathrm{x}}$ emissions after 3 May (Figs. 3, 4) favors the $\mathrm{O}_{3}$ increase in the VOC-sensitive environment.

As the episode evolves, 4-5 May, the $\mathrm{VOC} / \mathrm{NO}_{\mathrm{x}}$ ratios over Western Russia increase, and ends with $\mathrm{O}_{3}$ increases up to $40 \mathrm{ppb}$. During the next days, 6 and 7 May, the $\mathrm{O}_{3}$ plume is transported westwards and is enhanced over the Baltic Sea and Helsinki (70-90 ppb, Fig. 7). A second plume is extended over Germany and Denmark up to the North Sea, through a SSE-NNW axis (85-90 ppb) due to the accumulation of "new" $\mathrm{OH}$ radicals, produced under the favorable conditions of increased radiation and water vapor (Fig. 6). The $\mathrm{O}_{3}$ accumulation over Baltic and North Sea is also due to the lower deposition velocities. The decrease of fire intensity during the last days of the episode, 8-9 May, further increases the $\mathrm{VOC} / \mathrm{NO}_{\mathrm{x}}$ ratios up to $25 \mathrm{ppbC} \mathrm{ppb}^{-1}$ over the area (not shown) shifting the chemistry towards the $\mathrm{NO}_{\mathrm{x}}$ sensitive regime.

Over the fires dominated area, which is not so densely populated, a significant fraction of the VOC-OH oxidation rate $(30-40 \%)$ is due to the abundance of the $\mathrm{CO}$ fire emissions. Only a small fraction, $5 \%$, is attributed to isoprene. Downwind of the fire plume, the less reactive $\mathrm{CO}$ emissions, compared to VOC, arrive intact, and contribute to the VOC-OH oxidation rates by $50 \%$. Omitting $\mathrm{CO}$ from the fire gaseous mixture results in $\mathrm{O}_{3}$ decreases by $20-25 \%$ while without VOC the impact is lower, 5-10\% (not shown). During the 

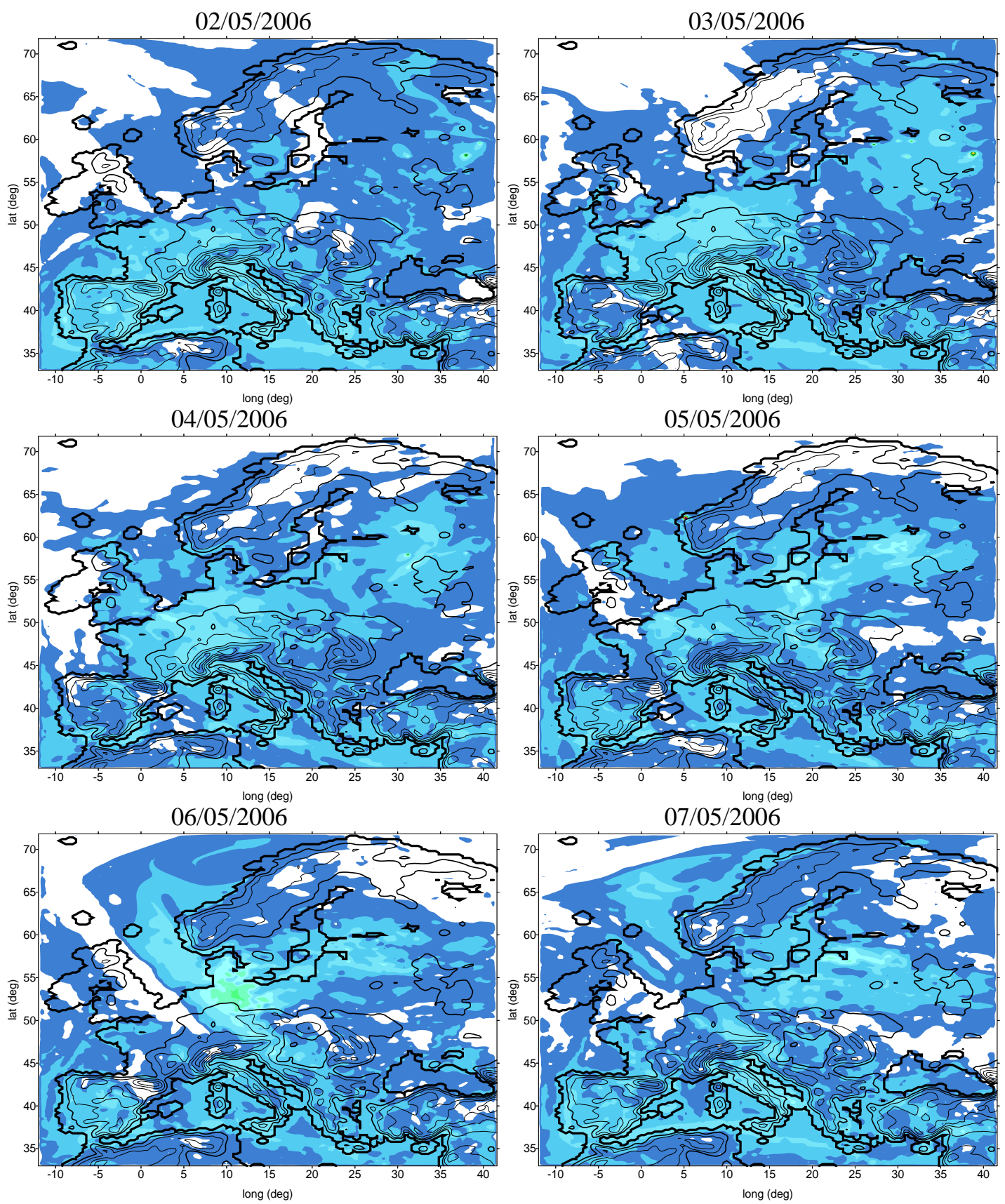

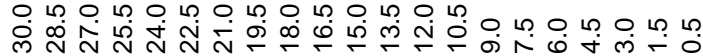

Fig. 6. Integrated hourly $\mathrm{VOC}\left(\mathrm{CO}\right.$ and $\mathrm{CH}_{4}$ are included $)-\mathrm{OH}$ oxidation rates $\left(\mathrm{ppbh}^{-1}\right)$ at the hour when the peak $\mathrm{O}_{3}$ concentration occurred during the period 2-7 May 2006.

days of maximum biogenic activity and decreased fire activity, isoprene contributes to the VOC-OH oxidation rates, up to $15 \%$ over Western Russia and 5\% over Eastern Europe.

Over the areas that are affected by the fresh fire plumes during 2-8 May, the slope between $\mathrm{O}_{3}$ and $\mathrm{CO}$ predictions is $0.0043 \pm 0.009 \mathrm{ppb} \mathrm{ppb}^{-1}$. Comparable values of
$\mathrm{O}_{3}$ production efficiency are reported in the literature for fresh biomass burning plumes but mainly in boreal regions (e.g. $0.005 \pm 0.019 \mathrm{ppb} \mathrm{ppb}^{-1}$ over Canada (Alvarado et al., 2010), $0.03 \pm 0.04 \mathrm{ppb} \mathrm{ppb}^{-1}$ over Siberia and North America (Singh et al., 2010), $0.14 \pm 0.50 \mathrm{ppb} \mathrm{ppb}^{-1}$ over Siberia (Paris et al., 2009). In the current study, the most efficient 

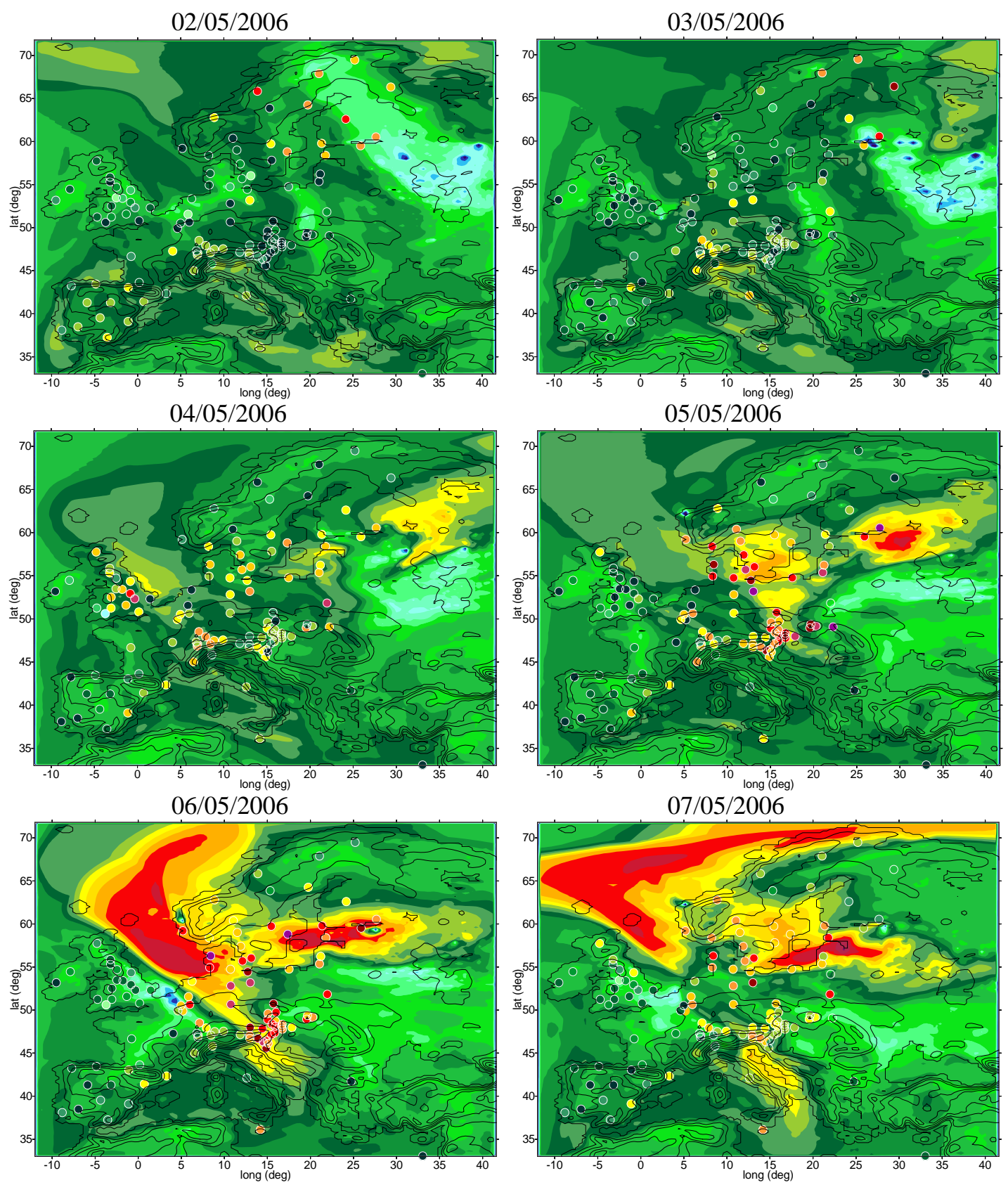

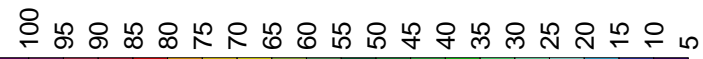

Fig. 7. Predicted (color shade) and observed (symbols) daily maximum hourly $\mathrm{O}_{3}$ concentrations (ppb) during 2-7 May 2006 for the reference run.

$\mathrm{O}_{3}$ production is taking place in the aged plumes reaching the northern edge of the modeling domain (slopes ranging between 0.019 and $0.045 \mathrm{ppb} \mathrm{ppb}^{-1}$ ), and especially under low CO load $\left(0.106 \mathrm{pp} \mathrm{ppb}^{-1}\right)$. Unfortunately, these values cannot be directly compared to the slopes measured $(0.34$ $\left.0.58 \mathrm{ppbpp}^{-1}\right)$ at the research Zeppelin station $\left(11.9^{\circ} \mathrm{E}\right.$, $78.9^{\circ} \mathrm{N}$ ) during the same period (Stohl et al., 2007) as it is not included in our modeling domain.

Finally, the main nitrogen reservoir species of the emitted fire $\mathrm{NO}_{\mathrm{x}}$ are nitric acid $\left(\mathrm{HNO}_{3}\right)$ and peroxyacetyl nitrate (PAN). Close to the fires and in fresh plumes, the $\mathrm{HNO}_{3}$ and PAN predictions are up to 22 and 3 ppb, respectively, while their fractions relative to the oxidized nitrogen species 


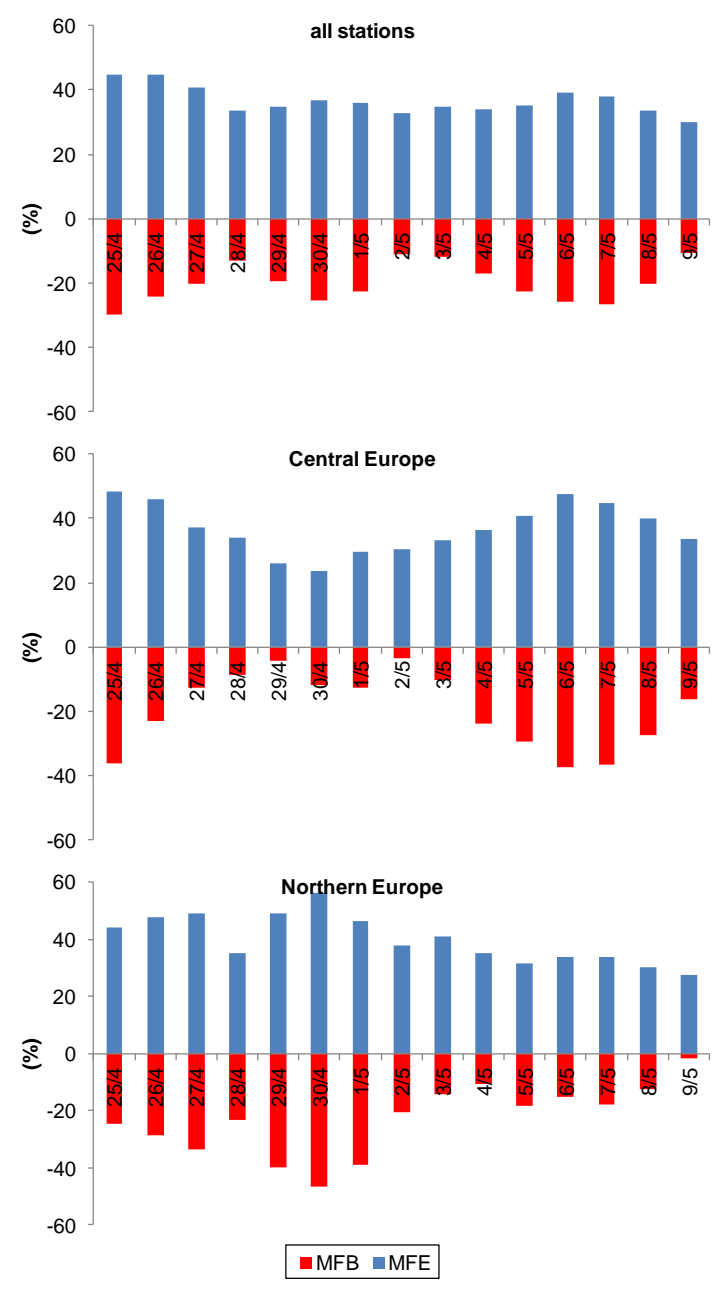

(a)

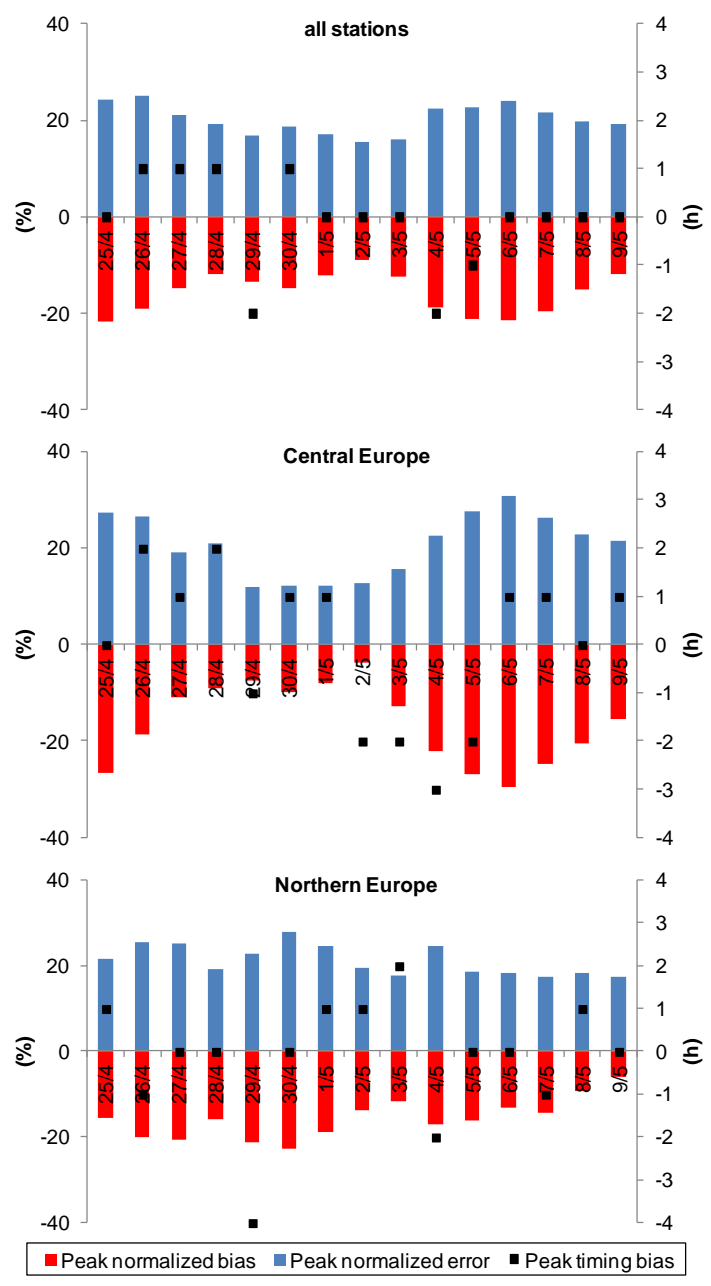

(b)

Fig. 8. Daily variation of the (a) MFB and MFE and (b) time-unpaired peak normalized bias, time-unpaired peak normalized error (left axis) and bias in peak timing (right axis) over all stations, and stations of Central and Northern Europe, during the period 25 April-9 May.

$\left(\mathrm{NO}_{\mathrm{y}}=\mathrm{NO}_{\mathrm{x}}+\mathrm{PAN}+\mathrm{HNO}_{3}+\right.$ nitrates $)$ are up to $25 \%$ and $5 \%$. The modeled PAN losses found over Northern Europe and Western Russia suggest a potential contribution to the $\mathrm{O}_{3}$ increase along the plume path as other researchers report as well (Jaffe and Wigder, 2012 and references therein).

\subsection{Comparison with $\mathrm{O}_{3}$ observations}

The model performance is assessed using average and peak statistical metrics. The statistical analysis includes the calculation of the predicted and observed average, the mean normalized bias (MNB), the mean normalized error (MNE), correlation values of predicted versus observed $\mathrm{O}_{3}$ concentrations, the mean fractional bias (MFB), the mean fractional error (MFE), the root mean square error (RMSE), and the time-paired and time-unpaired peak normalized bias and normalized error. The estimation of the statistical metrics for the whole period, over all stations and over the stations of Cen- tral and Northern Europe separately, is presented in Table 2. The metrics definition, according to US EPA, is presented in the Appendix A.

Though the model predictions follow successfully the observations' spatial distribution, an underestimation is apparent for both average and peak predictions (Table 2). The MNB for all stations is $-2.70 \%$, during the whole simulation period. The agreement is better over Central Europe $(\mathrm{MNB}=-0.13 \%)$ than over Northern Europe $(\mathrm{MNB}=-5.34 \%)$. The higher bias over Northern Europe is partly attributed to the model weakness to retain non-zero $\mathrm{O}_{3}$ concentrations in a number of stations, during the night hours. The day-by-day statistical processing reveals that the MNB and MNE over all stations vary between $-15.49 \%$ and $17.97 \%$ and between $30.21 \%$ and $59.02 \%$, respectively. The positive biases come from only a few observations (low values) that dominate the metric and for that purpose the MFB 

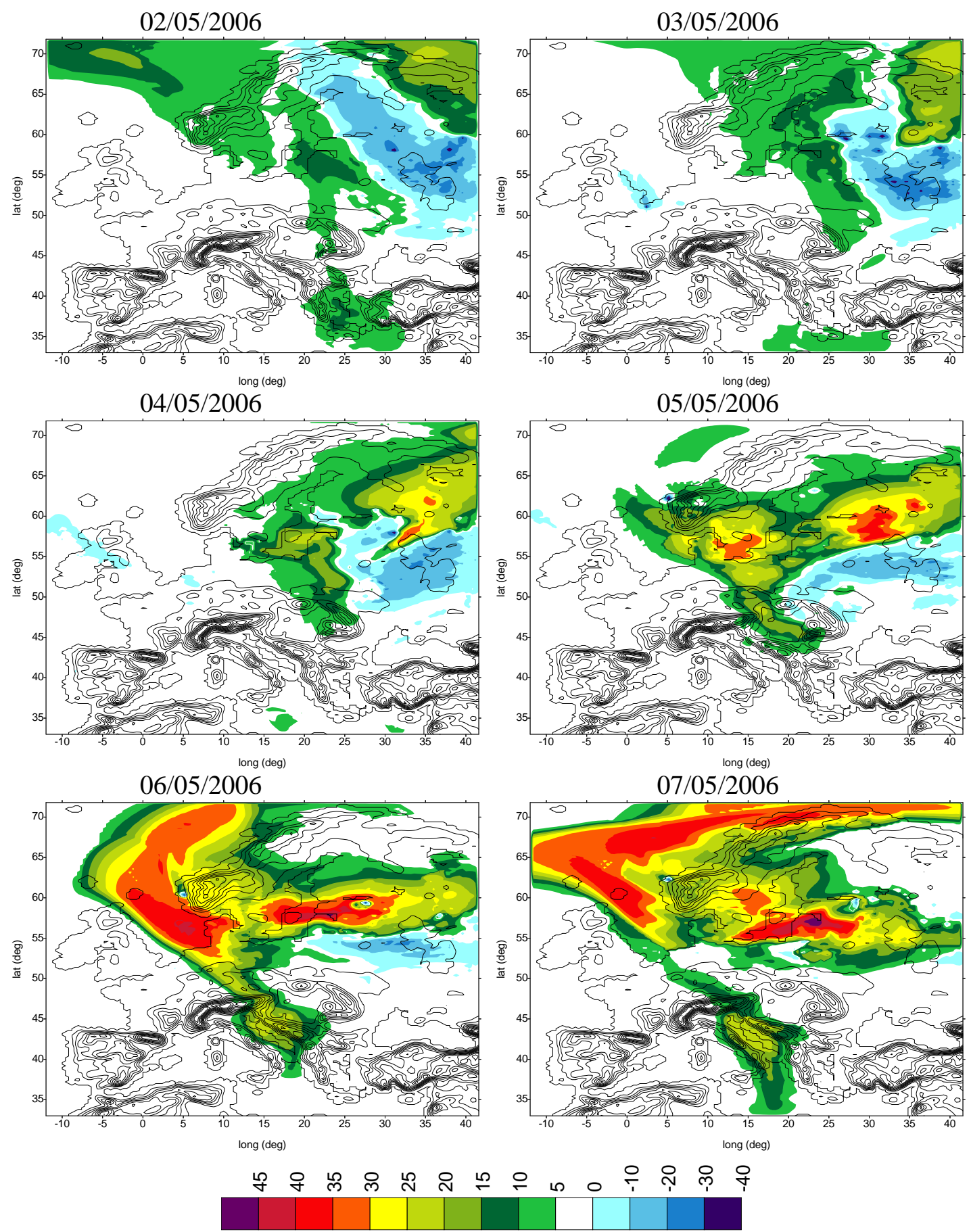

Fig. 9. Pure contribution of biomass burning emissions to maximum hourly surface $\mathrm{O}_{3}$ (ppb) during the period 2-7 May 2006 .

is also used where normalization is achieved not only by the observed quantity, but by the modeled quantities as well. The day-by-day variation of the MFB and MFE for all the stations as well as for the stations of Central and Northern Europe separately, are presented in Fig. 8a. During the first days of the simulation period (25 April-1 May), the model underestimates the observed concentrations over Northern Europe and specifically over Finland. However, the higher predictions after 2 May result to a decrease of biases over Northern Europe. The underestimation is still evident over Central Europe even during the days of maximum photochemical activity (4-8 May), probably due to late $\mathrm{O}_{3}$ plumes arrival to several stations (Fig. 7). The better correlation during the second period ( $r=0.49,2-9$ May) compared to the first 
Table 2. Statistical performance for $\mathrm{O}_{3}$ over all rural background monitoring stations of the EMEP network (stations of Northern Europe/stations of Central Europe). All the predicted-observed pairs are considered.

\begin{tabular}{lll}
\hline & $\begin{array}{l}\text { Reference run } \\
\mathrm{NO}_{\mathrm{x}} / \mathrm{CO}=0.06\end{array}$ & $\begin{array}{l}\text { AGRIC run } \\
\mathrm{NO}_{\mathrm{x}} / \mathrm{CO}=0.025\end{array}$ \\
\hline Average & & \\
\hline Average predicted $(\mathrm{ppb})$ & $36.3(35.8 / 35.9)$ & $38.9(41.6 / 36.6)$ \\
Average observed $(\mathrm{ppb})$ & $44.9(44.0 / 45.4)$ & $44.9(44.0 / 45.4)$ \\
MNB $(\%)$ & $-2.70(-5.34 /-0.13)$ & $2.09(5.37 / 0.94)$ \\
MFB $(\%)$ & $-20.06(-23.12 /-19.79)$ & $-14.07(-9.80 /-18.41)$ \\
MNE $(\%)$ & $40.35(39.99 / 44.27)$ & $39.22(37.64 / 43.87)$ \\
MFE $(\%)$ & $36.63(40.08 / 36.82)$ & $33.39(32.89 / 36.07)$ \\
RMSE (ppb) & $17.44(18.37 / 17.74)$ & $16.17(15.86 / 17.25)$ \\
\hline Peak & & \\
\hline Peak normalized bias time-paired $(\%)$ & $-34.98(-33.77 /-36.82)$ & $-27.26(-24.61 /-28.44)$ \\
Peak normalized error time-paired $(\%)$ & $34.98(33.77 / 36.82)$ & $28.42(26.16 / 29.55)$ \\
Peak normalized bias time-unpaired $(\%)$ & $-18.17(-15.12 /-20.73)$ & $-7.04(4.73 /-13.82)$ \\
Peak normalized error time-unpaired $(\%)$ & $19.37(16.09 / 21.99)$ & $20.28(23.0 / 18.41)$ \\
\hline Correlation $(r)$ & & \\
\hline 25 April-1 May (all stations) & 0.28 & 0.45 \\
2-9 May (all stations) & 0.49 & 0.54 \\
\hline
\end{tabular}

one ( $r=0.28,25$ April-1 May) is also observed in the scatter plots of the mean hourly predicted $\mathrm{O}_{3}$ concentrations versus the observed ones (not shown).

In contrast to the average metrics, the agreement of the peak metrics is better over the stations of Northern than Central Europe; the time-unpaired peak normalized bias is $-15.12 \%$ and $-20.73 \%$, respectively. The higher bias at Central Europe is associated with deviations at a number of stations covered by the core of the enhanced $\mathrm{O}_{3}$ plume (e.g. Poland, Austria, Slovakia). The day-by-day statistical processing over all stations reveals that the time-unpaired peak normalized bias ranges between $-8.90 \%$ and $-21.71 \%$ while over Central and Northern Europe it ranges between $-3.90 \%$ and $-29.59 \%$, and $-6.08 \%$ and $-22.88 \%$, respectively (Fig. 8b). The peak timing bias (difference between the predicted and observed peak hour) over all stations does not exceed $\pm 2 \mathrm{~h}$ during the entire simulation period (Fig. 8b).

\subsection{FS technique}

In order to calculate the pure, synergistic and total contributions of biomass burning and biogenic emissions to maximum surface $\mathrm{O}_{3}$, the results of the NOBIOG, NOFIRES and NOFIRES+NOBIOG simulations are employed the time the maximum hourly surface $\mathrm{O}_{3}$ concentration appears in each grid cell in the reference run.

\subsubsection{Pure contribution from individual source category}

In the framework of this study, the pure contribution represents the full potential of each source category (biomass burning or biogenic emissions) to produce $\mathrm{O}_{3}$ in the presence of anthropogenic sources. The pure contribution of fire emissions to maximum hourly surface $\mathrm{O}_{3}$ concentrations is presented for each day of the period 2-7 May in Fig. 9. It is evident that the pure contribution of fire emissions determines the spatial distribution of surface $\mathrm{O}_{3}$ over large parts of Europe (Fig. 7). According to the analysis presented in Sect. 3.1, fire emissions are strong $\mathrm{NO}_{\mathrm{x}}$ emitters and thus provoke $\mathrm{O}_{3}$ titration near the source. Close to the burnt areas and in areas characterized by low $\mathrm{VOC} / \mathrm{NO}_{\mathrm{x}}$ ratios, a negative contribution reaches up to $35 \mathrm{ppb}$. At the same time fires are positive contributors downwind, in more aged plumes, enhancing $\mathrm{O}_{3}$ production. The maximum contributions occur in areas where the environmental conditions are ideal for $\mathrm{O}_{3}$ production as over Western Russia, Eastern and Northern Europe, where the fires' pure contribution reaches up to $40-45 \mathrm{ppb}$. The higher potential of $\mathrm{O}_{3}$ production towards the end of the episode is related to the decline of the fire intensity and the elimination of $\mathrm{NO}_{\mathrm{x}}$ emissions in the VOC-sensitive environment.

The pure contribution of biogenic emissions is presented in Fig. 10. In the presence of only anthropogenic emissions, the $\mathrm{NO}_{\mathrm{x}}$-limited environment over Scandinavia, Eastern Europe and Western Russia eliminates the role of biogenic emissions, with a negligible or even negative $(-1 \mathrm{ppb})$ pure contribution. The areas characterized by negative contributions coincide with the areas of enhanced biogenic activity (Fig. 1). For the NOFIRES simulation and during the days of maximum photochemical activity, isoprene contributes to the VOC-OH oxidation rates (not shown), up to $25 \%$ over 

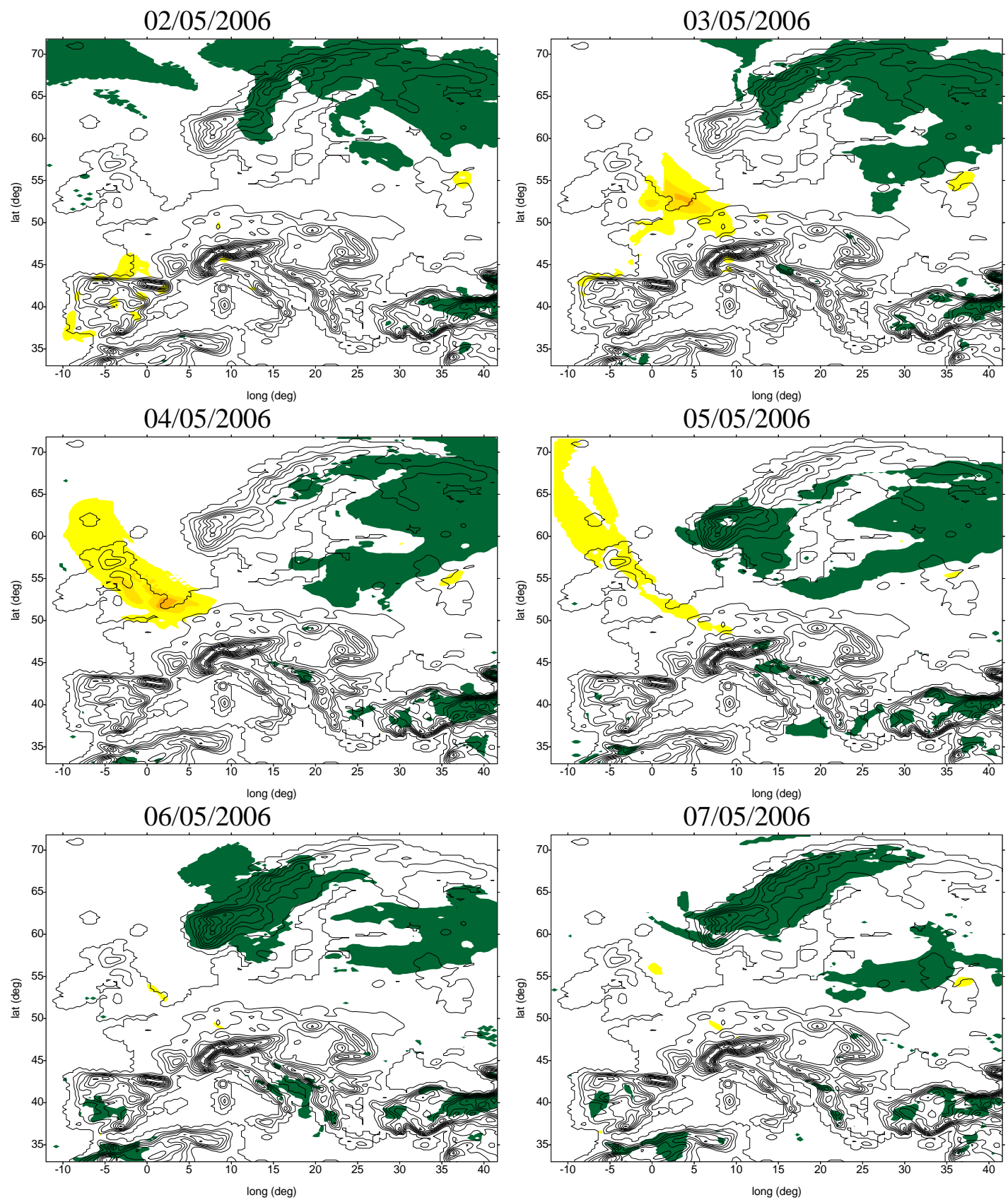

$\infty \wedge \omega$ ก

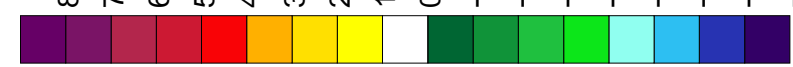

Fig. 10. Pure contribution of biogenic emissions to maximum hourly surface $\mathrm{O}_{3}$ (ppb) during the period 2-7 May 2006 .

Western Russia and $10 \%$ over Eastern Europe. These fractions are higher compared to the reference case, as the presence of fire VOC emissions depresses $\mathrm{OH}$ levels, thereby reduces the reactivity of BVOC emissions. However, under low $\mathrm{NO}_{\mathrm{x}}$ concentrations (NOFIRES simulation), the peroxy radicals, produced by VOC-OH oxidation, are removed from the system through radical-radical reactions, instead of partici- pating in chain reactions converting $\mathrm{NO}$ to $\mathrm{NO}_{2}$. Only over more populated areas (e.g. Moscow), the pure contribution of the order of $1 \mathrm{ppb}$ is positive.

Over the rest of Europe, the pure contribution of biogenic emissions does not exceed 2-3 ppb. The positive increase near UK, on 3 and 4 May, is attributed mainly to the interaction of BVOC emissions with ports activity. Despite the 
fact that biogenic activity over the southern Europe, exhibits the highest values in Europe, the lack of essential $\mathrm{NO}_{\mathrm{x}}$ leads to relatively small $\mathrm{O}_{3}$ increases. The same result (e.g. for Spain) has also been discussed by Curci et al. (2009). The negative contribution over Morocco and Tunisia is associated with ozonolysis of isoprene and terpenes and reflects mainly the poor model representation of anthropogenic emissions in these areas.

\subsubsection{Synergistic effect between biomass burning and biogenic emissions}

The synergy between a source and other source categories indicates if the mixing of both categories tends to limit or enhance the potential of any single source category in producing $\mathrm{O}_{3}$. The synergistic effect between biomass burning and biogenic emissions is presented in Fig. 11, along with the wind flow at 12:00 UTC. During the days of intense fire activity coinciding with low biogenic activity over the area of interest (up to 2 May), the synergistic effect is small, about $1 \mathrm{ppb}$, or even negligible. As the fire $\mathrm{NO}_{\mathrm{x}}$ plumes disperse over regions which also emit biogenic emissions (Western Russia and Scandinavia), they provide the necessary fuel for the peroxy radicals, produced by BVOC-OH oxidation, to participate in chain reactions converting $\mathrm{NO}$ to $\mathrm{NO}_{2}$. The negative synergistic effect over more populated areas (Moscow) is attributed to the addition of fire $\mathrm{NO}_{\mathrm{x}}$ emissions in an already urban VOC-environment that suppresses further $\mathrm{O}_{3}$ production by $1 \mathrm{ppb}$.

The synergistic effect becomes more apparent after 3 May, under the favorable conditions for the VOC chemistry discussed in the previous section, and it is maximized between 4 and 6 May. This effect becomes apparent in areas designated by enhanced biogenic activity but also by ideal environmental conditions to produce $\mathrm{O}_{3}$. For example, there is an apparent synergy between these two source categories over Northern Europe on 6 May, despite the fact that the pure effect of biogenic emissions is negative or negligible over this area (Fig. 10). As the fire plume passes over the Northern Europe it is enriched by reactive BVOC emissions and provokes a further $\mathrm{O}_{3}$ increase by up to $6 \mathrm{ppb}$. Downwind of the fire plumes, in areas characterized by favorable meteorological conditions and higher $\mathrm{VOC} / \mathrm{NO}_{\mathrm{x}}$ ratios (e.g. for ratios $>5 \mathrm{ppbC} \mathrm{ppb}^{-1}$; over Eastern Europe, on 5 May), the interaction between $\mathrm{BVOC}$ and fire emissions enhance the potential of each source in $\mathrm{O}_{3}$ formation by $8 \mathrm{ppb}$.

\subsubsection{Total contribution from individual source category}

The total (actual) contribution of fire emissions to maximum hourly surface $\mathrm{O}_{3}$ under the presence of both anthropogenic and biogenic source categories (not shown) does not significantly differ from the pure one (Fig. 9) indicating the critical role of biomass burning emissions in the examined area. Nev-
Table 3. Maximum positive and negative $\mathrm{O}_{3}$ differences between the sensitivity runs and the reference run.

\begin{tabular}{lll}
\hline & $\begin{array}{l}\text { Positive differences } \\
(\mathrm{ppb})\end{array}$ & $\begin{array}{l}\text { Negative differences } \\
(\mathrm{ppb})\end{array}$ \\
\hline AGRIC & $107.8 \pm 53.8$ & $-6.8 \pm 3.4$ \\
EMISS0.8 & $7.8 \pm 3.3$ & $-5.4 \pm 1.9$ \\
F1 & $4.2 \pm 1.8$ & $-1.8 \pm 0.72$ \\
F2 & $24.7 \pm 3.9$ & $-6.5 \pm 3.5$ \\
\hline
\end{tabular}

ertheless, higher values from the ones calculated for the pure contribution are estimated (up to $8 \mathrm{ppb}$ ) in the areas where the synergistic effect of the two emission categories is positive.

Regarding biogenic emissions, their total contribution to $\mathrm{O}_{3}$ production (Fig. 12), was found to almost coincide with the synergistic effect between the two sources, thus reflecting the critical role of fire emissions in their $\mathrm{O}_{3}$ forming potential. In particular, in areas where the pure contribution of biogenic emissions was found negative, the synergistic effect of these two emission categories reversed their final impact on the $\mathrm{O}_{3}$ production. During the days of maximum photochemical activity, the positive total contributions at the plumes areas reach up to $8 \mathrm{ppb}$.

Isoprene was found to be the major contributor to the $\mathrm{O}_{3}$ increases, by $80 \%$ (up to $6 \mathrm{ppb}$ ). Terpenes and BOVOC emissions have lower contribution, $0.5-1 \mathrm{ppb}$, probably because of the lower terpenes emissions and the low BOVOC reaction rates. Even though the emission load of isoprene and BOVOC categories is comparable, the methanol's $(99 \%$ of BOVOC) low oxidation rate by $\mathrm{OH}$ radical $\left(1600 \mathrm{ppm} \mathrm{min}^{-1}\right.$ compared to isoprene's $147600 \mathrm{ppm} \mathrm{min}^{-1}$ ) results in lower $\mathrm{O}_{3}$ productivity.

\subsection{Sensitivity to parameters of the fire emissions}

In this section, we present results from the sensitivity tests presented in Sect. 2. The examined key parameters of the fire emissions are the chemical composition, the magnitude and the injection height. The maximum positive and negative $\mathrm{O}_{3}$ differences between the sensitivity and the reference run following the methodology of von Kuhlmann et al. (2004) are presented in Table 3.

The composition of the gaseous mixture released by the fires is proven critical for the $\mathrm{O}_{3}-\mathrm{NO}_{\mathrm{x}}-\mathrm{VOC}$ sensitivity and the evolution of the episode. Studies demonstrate that the $\mathrm{NO}_{\mathrm{x}} / \mathrm{CO}$ emission ratio from the fires is highly uncertain and variable (Mason et al., 2001; McKeen et al., 2002) but very crucial for photochemistry (Alvarado et al., 2010; Jaffe and Wigder, 2012). Under the lower molar $\mathrm{NO}_{\mathrm{x}} / \mathrm{CO}$ ratio of 0.025 (AGRIC simulation), the $\mathrm{VOC} / \mathrm{NO}_{\mathrm{x}}$ ratios over Eastern Europe and Western Russia become quite high $\left(\sim 50 \mathrm{ppbC} \mathrm{ppb}^{-1}\right)$, compared to the reference run, mainly due to lower $\mathrm{NO}_{\mathrm{x}}$ emissions but also higher (by a factor of 1.3) VOC emissions (Fig. 4). Positive differences in 

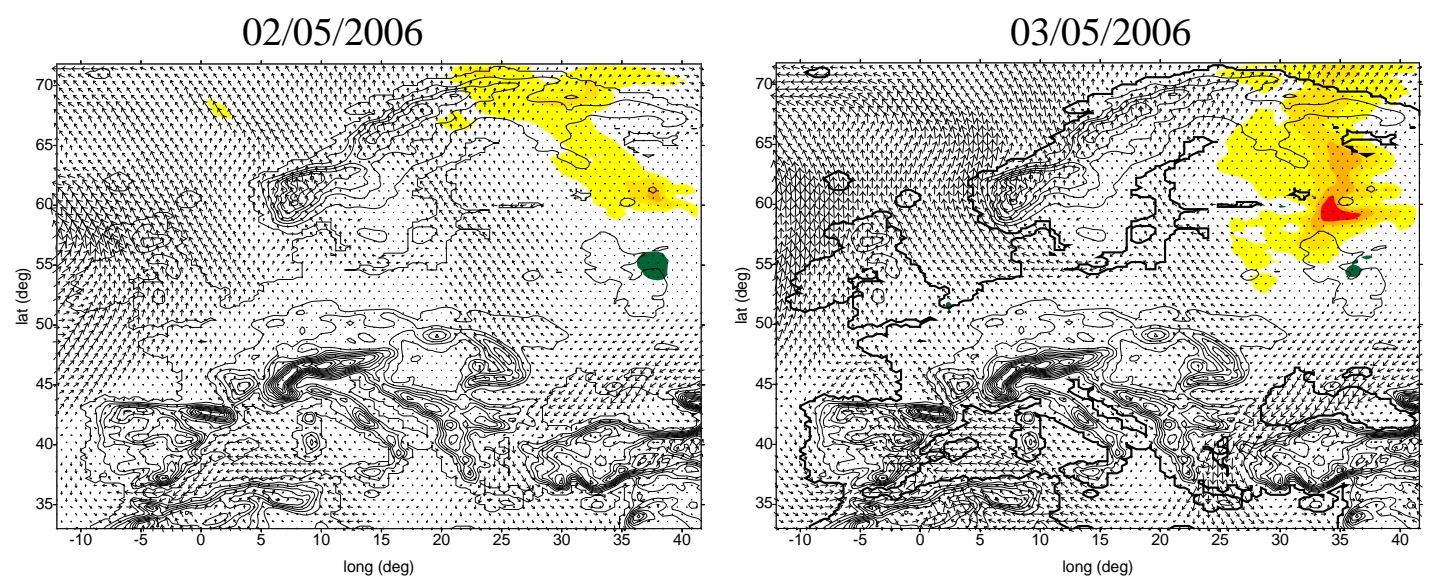

$04 / 05 / 2006$
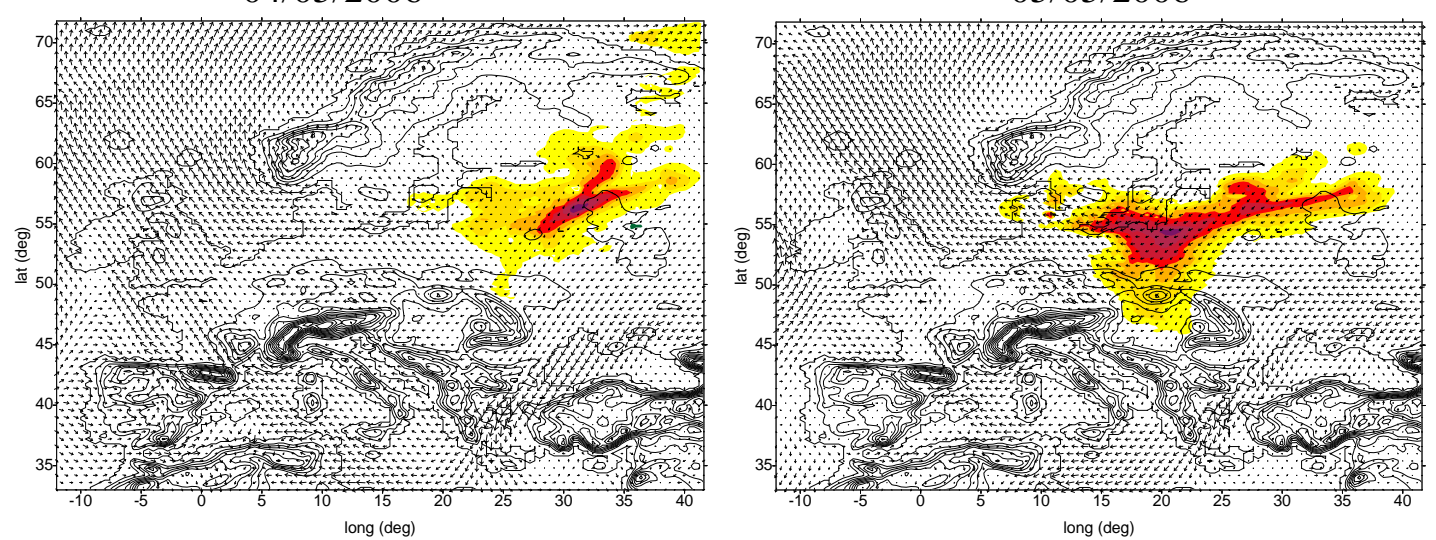

$06 / 05 / 2006$
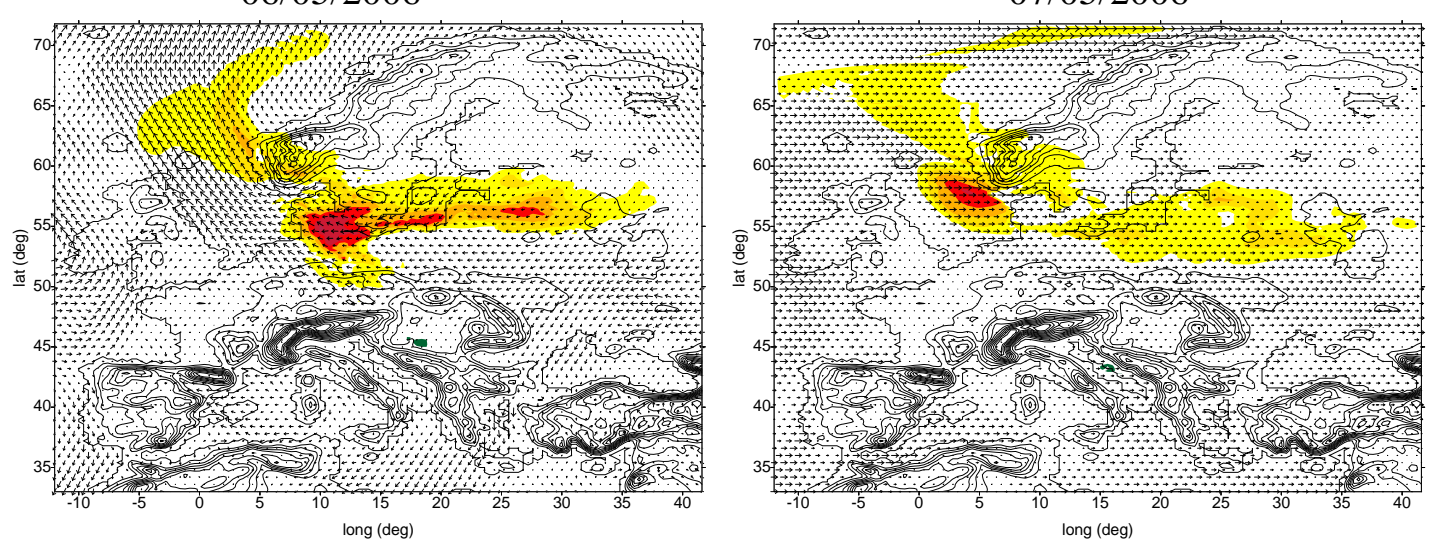

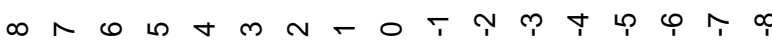

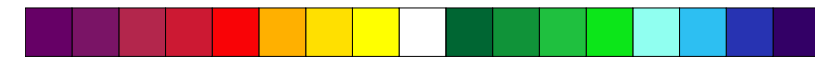

Fig. 11. Synergistic effect of biomass burning and biogenic emissions on maximum hourly surface $\mathrm{O}_{3}$ (ppb) during the period 2-7 May 2006. The wind flow at 12:00 UTC is shown.

maximum hourly $\mathrm{O}_{3}$ concentrations of $107.8 \pm 53.8 \mathrm{ppb}$ are predicted in relation to the reference run over the fires dominated areas. The higher increases are predicted during the days of higher fire intensity. The increased $\mathrm{O}_{3}$ concentrations are mainly attributed to the higher VOC-OH oxidation rates (by a factor of almost 2) at the fire spots, compared to the reference run. In addition, the prevention of $\mathrm{O}_{3}$ scavenging in their vicinity yields higher surface $\mathrm{O}_{3}$ concentrations by a factor of 2, during the whole simulation period. The lower $\mathrm{NO}_{\mathrm{x}} / \mathrm{CO}$ ratio ends in a significant reduction of the biases (Table 2). In the areas characterized by rich-in $\mathrm{O}_{3}$ plumes, the low ratio yields higher $\mathrm{O}_{3}$ predictions (up to $60 \mathrm{ppb}$ ), while 

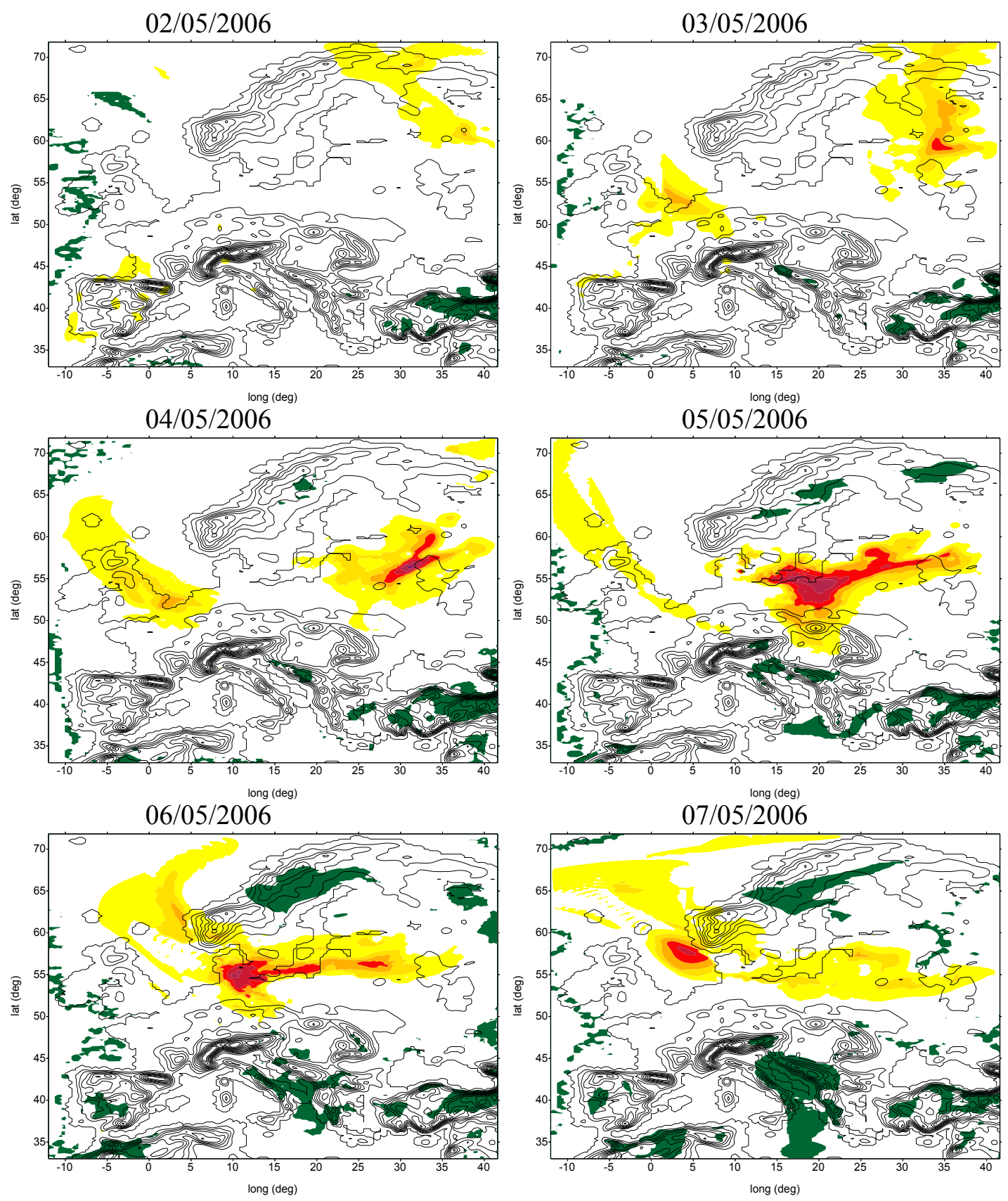

$\infty$ N

Fig. 12. Total contribution of biogenic emissions to maximum hourly surface $\mathrm{O}_{3}$ (ppb) during the period 2-7 May 2006 .

the predictions over Central Europe change only slightly. However, the predictions over Scandinavia overestimate the observations by up to $50 \%$. The highest negative differences ( $\sim 15 \mathrm{ppb}$ ), in relation to the reference run, are observed during the last days of the episode characterized by decreased fire intensity.
Regarding NOy species, our findings are in conjunction with the findings of Alvarado et al. (2010) and Jaffe and Wigder (2012) even though a straightforward comparison is not possible as they mainly refer to boreal fires. In particular, it turns out that as the molar $\mathrm{NO}_{\mathrm{x}} / \mathrm{CO}$ ratio reduces ( 0.025 versus 0.06 in the reference run) a greater fraction of $\mathrm{NO}_{\mathrm{x}}$ is sequestered in the form of PAN. For the lower ratio, 
the PAN/NOy and $\mathrm{HNO}_{3} / \mathrm{NOy}$ fractions are up to $50-60 \%$ and $20-30 \%$, respectively. Despite the fact that agricultural residues emit lower $\mathrm{NO}_{\mathrm{x}}$ emissions than grass, the PAN predictions are higher, compared to the reference run, by up to $15 \mathrm{ppb}$.

The predictions are less sensitive on the magnitude of fire emissions. According to Ichoku and Kaufman (2005), the methodology to convert the FRP to PM emission fluxes, used in this study, involves uncertainties and a possible overestimation of PM emission fluxes by $50 \%$. In order to deal with these uncertainties, a simulation with a $20 \%$ cut-off of all fire emissions has been conducted (EMISS0.8 simulation). The maximum increase on hourly surface $\mathrm{O}_{3}$ concentrations invoked by the emissions' reduction is $7.8 \pm 3.3 \mathrm{ppb}$ in relation to the reference run and is taking place close to the fire spots where $\mathrm{O}_{3}$ titration by $\mathrm{NO}$ prevails. Negative differences of $-5.4 \pm 1.9 \mathrm{ppb}$ are predicted inside the more aged and richin $\mathrm{O}_{3}$ plumes (Eastern and Northern Europe, Western Russia) whose chemistry is primarily controlled by $\mathrm{NO}_{\mathrm{x}}$-availability.

Literature review agrees that Eastern Europe and Russia are the greatest contributors to agricultural fires injecting the fires smoke mostly within the mixing layer (Labonne et al., 2007; Sofiev et al., 2009; Amiridis et al., 2010). Although the fire event investigated in this study is a grass fire event, some authors claim that emissions from forest and mixed areas are also substantial (e.g. Labonne et al., 2007), injecting releases above the PBL. In the first scenario (F1), the daily maximum injection height is set spatially and temporally constant (as in the reference run) and is determined by the calculated daily maximum PBL height over the burnt area (2-4 May $2.3 \pm 0.2 \mathrm{~km}, 5$ May $2.4 \pm 0.2 \mathrm{~km}, 6$ May $2.2 \pm 0.3 \mathrm{~km}$, 7 May $1.8 \pm 0.4 \mathrm{~km}, 8$ May $1.6 \pm 0.3 \mathrm{~km}$ ). According to F1, the $50 \%$ of fire emissions load is distributed up to $500 \mathrm{~m}$, as in the reference run while the remaining $50 \%$ is distributed uniformly up to the PBL height. The second scenario (F2) assesses the impact of possible crown fires based on the assumptions of Leung et al. (2007). According to this scenario, a large fraction $(60 \%)$ of the emissions of the reference run is injected above the top of the PBL up to $5 \mathrm{~km}$, while the rest $(40 \%)$ of the fire emissions represents emissions from surface fuels and is uniformly distributed up to a representative average PBL height over the burnt area $(2.5 \mathrm{~km})$.

The maximum positive differences in the hourly surface $\mathrm{O}_{3}$ concentrations, between $\mathrm{F} 1$ and the reference run, are $4.2 \pm 1.8 \mathrm{ppb}$ and appear in the vicinity of the fires. The highest increases $(7.2 \mathrm{ppb})$ are predicted during the days of maximum photochemical activity. The release of fire emissions up to higher altitudes favors the $\mathrm{O}_{3}$ enhancement within the PBL which under favorable conditions is mixed downward increasing surface concentrations. As in the case of the EMISS0.8 simulation, negative differences of $-1.8 \pm 0.72 \mathrm{ppb}$ are predicted inside the more aged and richin $\mathrm{O}_{3}$ plumes. In case of the $\mathrm{F} 2$ scenario, the lower $\mathrm{NO}_{\mathrm{x}}$ emissions, both at the surface and inside the PBL, in relation to the reference run, enhance $\mathrm{O}_{3}$ production in the fires dominated areas by $24.7 \pm 3.9 \mathrm{ppb}$ but provoke maximum negative differences of $-6.5 \pm 3.5 \mathrm{ppb}$ in the rich-in $\mathrm{O}_{3}$ plume, along the SSE-NNW axis. The much greater $\mathrm{O}_{3}$ production during boreal fires in case of emissions lofted above the boundary layer was also found by Leung et al. (2007).

\section{Conclusions}

In the framework of this modeling study, the contribution of biomass burning emissions to $\mathrm{O}_{3}$ production is investigated using an $\mathrm{O}_{3}$ episode over Europe caused by numerous smallscale dry-grass fires over Western Russia. In this environment, the effect of the biogenic emissions is also quantified.

For the reference run $\left(\mathrm{NO}_{\mathrm{x}} / \mathrm{CO}\right.$ molar ratio equal to 0.06$)$, the model predictions successfully follow the observations' spatial distribution, however an underestimation is visible for both average ( $\mathrm{MNB}=-2.70 \%)$ and peak predictions (timeunpaired peak normalized bias $=-18.17 \%$ ). In contrast to the average metrics, the agreement of the peak metrics is better over the stations of Northern than Central Europe. The comparison with isoprene observations at stations of the EMEP network shows that isoprene estimations, based on MEGAN algorithm, are quite satisfactory preserving in general the observations order of magnitude.

Biomass burning is proven critical for the episode evolution but also for the $\mathrm{O}_{3}$ forming potential of biogenic emissions. Under the presence of only anthropogenic sources (pure contribution), biomass burning contributes up to $45 \mathrm{ppb}$ to maximum hourly surface $\mathrm{O}_{3}$, while the contribution of biogenic emissions is negligible or even negative. However, the synergistic effect of the two source categories has the potential to reverse the pure impact of biogenic emissions contributing up to $8 \mathrm{ppb}$. The synergistic effect is apparent in areas either characterized by peak biogenic emissions strength or by the appropriate environmental conditions that favor $\mathrm{O}_{3}$ increases namely the meteorological conditions and the $\mathrm{O}_{3}$ $\mathrm{NO}_{\mathrm{x}}$-VOC sensitivity of the areas crossing the fire plumes.

The cut-off of fire emissions by $20 \%$ and the change of their vertical distribution, inside the PBL end in maximum $\mathrm{O}_{3}$ differences of $7.8 \pm 3.3 \mathrm{ppb}$ and $4.2 \pm 1.8 \mathrm{ppb}$, respectively in relation to the reference run. Predictions were found to be more sensitive on the chemical composition of fire emissions. Under a lower fire $\mathrm{NO}_{\mathrm{x}} / \mathrm{CO}$ molar ratio $(0.025$, agricultural residues), higher $\mathrm{O}_{3}$ production rates at the fire spots and lower $\mathrm{O}_{3}$ scavenging in their vicinity end in maximum $\mathrm{O}_{3}$ differences of $107.8 \pm 53.8 \mathrm{ppb}$ in relation to the reference run. For both molar ratios, nitric acid and peroxyacetyl nitrate are the major contributors of reactive nitrogen reservoir species, accounting for about $25 \%$ and $5 \%$ for the high molar ratio and $20-30 \%$ and $50-60 \%$ for the lower one. 


\section{Appendix A}

\section{Average statistics}

$N$ is the product of the number of simulation hours and the number of monitoring locations, $C_{o}$ is the observed value, $C_{p}$ is the predicted value.

$$
\begin{aligned}
& \text { Average Predicted }=\frac{1}{N} \sum_{i=1}^{N} C_{p_{i}} \text {, Average Observed } \\
& =\frac{1}{N} \sum_{i=1}^{N} C_{o_{i}}, \\
& \text { Mean Normalized Bias }=\frac{100}{N} \sum_{i=1}^{N}\left(\frac{C_{p_{i}}-C_{o_{i}}}{C_{o_{i}}}\right), \\
& \text { Mean Normalized Error }=\frac{100}{N} \sum_{i=1}^{N}\left|\frac{C_{p_{i}}-C_{o_{i}}}{C_{o_{i}}}\right| \\
& \text { Mean Fractional Bias }=\frac{200}{N} \sum_{i=1}^{N}\left(\frac{C_{p_{i}}-C_{o_{i}}}{C_{p_{i}}+C_{o_{i}}}\right) \\
& \text { Mean Fractional Error }=\frac{200}{N} \sum_{i=1}^{N}\left|\frac{C_{p_{i}}-C_{o_{i}}}{C_{p_{i}}+C_{o_{i}}}\right| \\
& \text { RMSE } \left.=\sqrt{\frac{1}{N} \sum_{i=1}^{N}\left(C_{p_{i}}-C_{o_{i}}\right.}\right)
\end{aligned}
$$

\section{Peak statistics}

$N$ is the number of monitoring stations, $C_{o}\left(x, t^{\prime}\right)_{\max }$ and $C_{p}(x, t)_{\max }$ are the maximum hourly observed and predicted concentrations at a specific monitoring station over a time period, $C_{p}\left(x, t^{\prime}\right)_{\max }$ is the maximum hourly predicted concentration at the same monitoring station at the time of the observed peak.

Time-paired peak normalized bias $=$

$$
\frac{100}{N} \sum_{i=1}^{N} \frac{C_{p}\left(x, t^{\prime}\right)_{\max }-C_{o}\left(x, t^{\prime}\right)_{\max }}{C_{o}\left(x, t^{\prime}\right)_{\max }},
$$

Time-paired peak normalized error $=$

$$
\frac{100}{N} \sum_{i=1}^{N}\left|\frac{C_{p}\left(x, t^{\prime}\right)_{\max }-C_{o}\left(x, t^{\prime}\right)_{\max }}{C_{o}\left(x, t^{\prime}\right)_{\max }}\right|,
$$

Time-unpaired peak normalized bias $=$

$$
\frac{100}{N} \sum_{i=1}^{N} \frac{C_{p}(x, t)_{\max }-C_{o}\left(x, t^{\prime}\right)_{\max }}{C_{o}\left(x, t^{\prime}\right)_{\max }}
$$

Time-unpaired peak normalized error $=$

$$
\frac{100}{N} \sum_{i=1}^{N}\left|\frac{C_{p}(x, t)_{\max }-C_{o}\left(x, t^{\prime}\right)_{\max }}{C_{o}\left(x, t^{\prime}\right)_{\max }}\right|
$$

\footnotetext{
Supplementary material related to this article is available online at: http://www.atmos-chem-phys.net/12/ 7931/2012/acp-12-7931-2012-supplement.pdf.
}

Acknowledgements. This paper has been part of the actions COST728 and COSTES0602.

Edited by: S. Galmarini

\section{References}

Alessio, G. A., De Lillis, M., Fanelli, M., Pinelli, P., and Loreto, F.: Direct and indirect impacts of fire on the isoprenoids emission from Mediterranean vegetation, Funct. Ecol., 18, 357-364, 2004.

Alvarado, M. J. and Prinn, R. G.: Formation of ozone and growth of aerosols in young smoke plumes from biomass burning: 1. Lagrangian parcel studies, J. Geophys. Res., 114, D09306, doi:10.1029/2008JD011144, 2009.

Alvarado, M. J., Logan, J. A., Mao, J., Apel, E., Riemer, D., Blake, D., Cohen, R. C., Min, K.-E., Perring, A. E., Browne, E. C., Wooldridge, P. J., Diskin, G. S., Sachse, G. W., Fuelberg, H., Sessions, W. R., Harrigan, D. L., Huey, G., Liao, J., Case-Hanks, A., Jimenez, J. L., Cubison, M. J., Vay, S. A., Weinheimer, A. J., Knapp, D. J., Montzka, D. D., Flocke, F. M., Pollack, I. B., Wennberg, P. O., Kurten, A., Crounse, J., Clair, J. M. St., Wisthaler, A., Mikoviny, T., Yantosca, R. M., Carouge, C. C., and Le Sager, P.: Nitrogen oxides and PAN in plumes from boreal fires during ARCTAS-B and their impact on ozone: an integrated analysis of aircraft and satellite observations, Atmos. Chem. Phys., 10, 9739-9760, doi:10.5194/acp-10-9739-2010, 2010.

Amiridis, V., Giannakaki, E., Balis, D. S., Gerasopoulos, E., Pytharoulis, I., Zanis, P., Kazadzis, S., Melas, D., and Zerefos, C.: Smoke injection heights from agricultural burning in Eastern Europe as seen by CALIPSO, Atmos. Chem. Phys., 10, 1156711576, doi:10.5194/acp-10-11567-2010, 2010.

Andreae, M. O. and Merlet, P.: Emissions of trace gases and aerosols from biomass burning, Global Biogeochem. Cy., 15, 955-966, 2001.

Arneth, A., Monson, R. K., Schurgers, G., Niinemets, U., and Palmer, P. I.: Why are estimates of global terrestrial isoprene emissions so similar (and why is this not so for monoterpenes)?, Atmos. Chem. Phys., 8, 4605-4620, doi:10.5194/acp-8-46052008, 2008.

Beekmann, M. and Vautard, R.: A modelling study of photochemical regimes over Europe: robustness and variability, Atmos. Chem. Phys., 10, 10067-10084, doi:10.5194/acp-1010067-2010, 2010.

Bytnerowicz, A., Cayan, D., Riggan, P., Schilling, S., Dawson, P., Tyree, M., Wolden, L., Tissell, R., and Preisler, H.: Analysis of the effects of combustion emissions and santa ana winds on ambient ozone during the October 2007 southern California wildfires, Atmos. Environ., 44, 678-687, 2010.

Carvalho, A., Monteiro, A., Flannigan, M., Solman, S., Miranda, A. I., and Borrego, C.: Forest fires in a changing climate and their impacts on air quality, Atmos. Environ., 45, 5545-5553, 2011.

Chang, J. S., Brost, R. A., Isaksen, I. S. A., Madronich, S., Middleton, P., Stockwell, W. R., and Walcek, C. J.: A three-dimensional eulerian acid deposition model: physical concepts and formulation, J. Geophys. Res., 92, 14681-14700, 1987.

Chen, F. and Dudhia, J.: Coupling and advanced land surfacehydrology model with the Penn State-NCAR MM5 modeling system - Part I: Model implementation and sensitivity, Mon. Weather Rev., 129, 569-585, 2001. 
Cheng, L., McDonald, K. M., Angle, R. P., and Sandhu, H. S.: Forest fire enhanced photochemical air pollution. A case study, Atmos. Environ., 32, 673-681, 1998.

Chung, Y.-S: On the forest fires and the analysis of air quality data and total atmospheric ozone, Atmos. Environ., 18, 2153-2157, 1984.

Curci, G., Beekmann, M., Vautard, R., Smiatek, G., Steinbrecher, R., Theloke, J., and Friedrich, R.: Modeling study of the impact of isoprene and terpene biogenic emissions on European ozone levels, Atmos. Environ., 43, 1444-1455, 2009.

Damoah, R., Spichtinger, N., Forster, C., James, P., Mattis, I., Wandinger, U., Beirle, S., Wagner, T., and Stohl, A.: Around the world in 17 days - hemispheric-scale transport of forest fire smoke from Russia in may 2003, Atmos. Chem. Phys., 4, 1311-1321, 10,

http://www.atmos-chem-phys.net/4/1311/10/.5194/acp-4-13112004, 2004.

Dudhia, J.: Numerical study of convection observed during the winter monsoon experiment using a mesoscale two-dimensional model, J. Atmos. Sci., 46, 3077-3107, 1989.

Environ: User's guide to the comprehensive air quality model with extensions (CAMx), version 4.10s, report, ENVIRON Int. Corp., Novato, CA, USA, 2004.

Forster, C., Wandinger, U., Wotawa, G., James, P., Mattis, I., Althausen, D., Simmonds, P., O'Doherty, S., Jennings, S. G., Kleefeld, C., Schneider, J., Trickl, T., Kreipl, S., Jäger, H., and Stohl, A.: Transport of boreal forest fire emissions from Canada to Europe, J. Geophys. Res., 106, 22887-22906, doi:10.1029/2001jd900115, 2001.

Fu, J. S., Hsu, N. C., Gao, Y., Huang, K., Li, C., Lin, N. H., and Tsay, S. C.: A regional chemical transport modeling to identify the influences of biomass burning during 2006 BASE-ASIA, Atmos. Chem. Phys. Discuss., 11, 3071-3115, doi:10.5194/acpd11-3071-2011, 2011.

Gery, M. W., Whitten, G. Z., Killus, J. P., and Dodge, M. C.: A Photochemical Kinetics Mechanism for Urban and Regional Scale Computer Modeling, J. Geophys. Res., 94, 925-956, 1989.

Girgždienè, R. and Byčenkienè, S.: Utilizing satellite data to highlight high ozone concentration events during fire episodes, in: Use of Satellite and In-situ Data to Improve Sustainability, NATO Science for Peace and Security Series C: Environmental Security, edited by: Kogan, F., Powell, A., and Fedorov, O., Springer Netherlands, 191-198, Part 4, doi:10.1007/978-90-4819618-0_22, 2011.

Goode, J. G., Yokelson, R. J., Ward, D. E., Susott, R. A., Babbitt, R. E., Davies, M. A., and Hao, W. M.: Measurements of excess $\mathrm{O}_{3}, \mathrm{CO}_{2}, \mathrm{CO}, \mathrm{CH}_{4}, \mathrm{C}_{2} \mathrm{H}_{4}, \mathrm{C}_{2} \mathrm{H}_{2}, \mathrm{HCN}, \mathrm{NO}, \mathrm{NH}_{3}$, $\mathrm{HCOOH}, \mathrm{CH} 3 \mathrm{COOH}, \mathrm{HCHO}$, and $\mathrm{CH}_{3} \mathrm{OH}$ in 1997 Alaskan biomass burning plumes by airborne Fourier transform infrared spectroscopy (AFTIR), J. Geophys. Res., 105, 22147-22166, doi:10.1029/2000jd900287, 2000.

Grell, G. A.: Prognostic evaluation of assumptions used by cumulus parameterizations, Mon. Weather Rev., 121, 764-787, 1993.

Grell, G. A., Dudhia, J., and Stauffer, D.: A description of the fifthgeneration Penn state/NCAR mesoscale model (MM5), NCAR technical note, NCAR/TN-398 +STR, National Centre for Atmospheric Sciences, Boulder, CO, USA, 138 pp., 1994.

Guenther, A., Hewitt, N., Erickson, D., Fall, R., Geron, C., Graedel, T., Harley, P., Klinger, L., Lerdau, M., McKay,W., Pierce, T., Sc- holes, B., Steinbrecher, R., Tallamraju, R., Taylor, J., and Zimmerman, P.: A global model of natural volatile organic compound emissions, J. Geophys. Res., 100, 8873-8892, 1995.

Guenther, A., Karl, T., Harley, P., Wiedinmyer, C., Palmer, P. I., and Geron, C.: Estimates of global terrestrial isoprene emissions using MEGAN (Model of Emissions of Gases and Aerosols from Nature), Atmos. Chem. Phys., 6, 3181-3210, doi:10.5194/acp-63181-2006, 2006.

Hodnebrog, Ø., Solberg, S., Stordal, F., Svendby, T. M., Simpson, D., Gauss, M., Hilboll, A., Pfister, G. G., Turquety, S., Richter, A., Burrows, J. P., and Denier van der Gon, H. A. C.: A model study of the Eastern Mediterranean ozone levels during the hot summer of 2007, Atmos. Chem. Phys. Discuss., 12, 7617-7675, doi:10.5194/acpd-12-7617-2012, 2012.

Hodzic, A., Vautard, R., Chepfer, H., Goloub, P., Menut, L., Chazette, P., Deuzé, J. L., Apituley, A., and Couvert, P.: Evolution of aerosol optical thickness over Europe during the August 2003 heat wave as seen from CHIMERE model simulations and POLDER data, Atmos. Chem. Phys., 6, 1853-1864, doi:10.5194/acp-6-1853-2006, 2006.

Hong, S.-Y. and Pan, H.-L.: Nonlocal Boundary-Layer vertical diffusion in a medium-range forecast model, Mon. Weather Rev., 124, 2322-2339, 1996.

Huang, M., Carmichael, G. R., Spak, S. N., Adhikary, B., Kulkarni, S., Cheng, Y., Wei, C., Tang, Y., D’Allura, A., Wennberg, P. O., Huey, G. L., Dibb, J. E., Jimenez, J. L., Cubison, M. J., Weinheimer, A. J., Kaduwela, A., Cai, C., Wong, M., Pierce, R. B., Al-Saadi, J. A., Streets, D. G., and Zhang, Q.: Multi-scale modeling study of the source contributions to nearsurface ozone and sulfur oxides levels over California during the ARCTAS-CARB period, Atmos. Chem. Phys., 11, 3173-3194, doi:10.5194/acp-11-3173-2011, 2011

Ichoku, C. and Kaufman, J. Y: A Method to Derive Smoke Emission Rates From MODIS Fire Radiative Energy Measurements, IEEE T. Geosci. Remote, 43, 2636-2649, 2005.

Jaffe, D., Chand, D., Hafner, W., Westerling, A., and Spracklen, D.: Influence of fires on $\mathrm{O}_{3}$ concentrations in the Western U.S, Environ. Sci. Technol., 42, 5885-5891, doi:10.1021/es800084k, 2008.

Jaffe, D. A. and Wigder, N. L.: Ozone production from wildfires: A critical review, Atmos. Environ., 51, 1-10, doi:10.1016/j.atmosenv.2011.11.063, 2012.

Jost, C., Trentmann, J., Sprung, D., Andreae, M. O., McQuaid, J. B., and Barjat, H.: Trace gas chemistry in a young biomass burning plume over Namibia: Observations and model simulations, J. Geophys. Res., 108, 8482, doi:10.1029/2002jd002431, 2003.

Junquera V., Russell, M. M., Vizuete, W., Kimura, Y., and Allen, D.: Wildfires in eastern Texas in August and September 2000: emissions, aircraft measurements, and impact on photochemistry, Atmos. Environ., 39, 4983-4996, 2005.

Kogan, F., Powell, A., Fedorov, O., Girgždienè, R., and Byčenkiende, S.: Utilizing Satellite Data to Highlight High Ozone Concentration Events During Fire Episodes, in: Use of Satellite and In-Situ Data to Improve Sustainability, NATO Science for Peace and Security Series, Springer Netherlands, 191-198, 2011.

Konovalov, I. B., Beekmann, M., Kuznetsova, I. N., Yurova, A., and Zvyagintsev, A. M.: Atmospheric impacts of the 2010 Russian wildfires: integrating modelling and measurements of an extreme air pollution episode in the Moscow region, Atmos. Chem. Phys., 
11, 10031-10056, doi:10.5194/acp-11-10031-2011, 2011.

Labonne, M., Breon, F.-M., and Chevallier, F.: Injection height of biomass burning aerosols as seen from a spaceborne lidar, Geophys. Res. Lett., 34, L11806, doi:10.1029/2007GL029311, 2007.

Ladstätter-Weißenmayer, A., Meyer-Arnek, J., Richter, A., Wittrock, F., and Burrows, J. P.: Tropospheric $\mathrm{O}_{3}$ over Indonesia during biomass burning events measured with GOME (Global Ozone Monitoring Experiment) and compared with trajectory analysis, Atmos. Chem. Phys. Discuss., 5, 3105-3130, doi:10.5194/acpd-5-3105-2005, 2005.

Leung, F.-Y. T., Logan, J. A., Park, R., Hyer, E., Kasischke, E., Streets, D., and Yurganov, L.: Impacts of enhanced biomass burning in the boreal forests in 1998 on tropospheric chemistry and the sensitivity of model results to the injection height of emissions, J. Geophys. Res., 112, D10313, doi:10.1029/2006jd008132, 2007.

Madronich, S.: UV radiation in the natural and perturbed atmosphere, in Environmental Effects of UV (Ultraviolet) Radiation, edited by: Tevini, M., Lewis Publisher, Boca Raton, FL, USA, 17-69, 1993.

Madronich, S.: The Tropospheric Visible Ultra-violet (TUV) model web page. National Center for Atmospheric Research, Boulder, CO, http://acd.ucar.edu/TUV/, 2002. Marufu, L., Dentener, F., Lelieveld, J., Andreae, M. O., and Helas, G.: Photochemistry of the African troposphere: Influence of biomassburning emissions, J. Geophys. Res., 105, 14513-14530, doi:10.1029/1999jd901055, 2000.

Marufu, L., Dentener, F., Lelieveld, J., Andreae, M. O., and Helas, G.: Photochemistry of the African troposphere: Influence of biomass-burning emissions, J. Geophys. Res., 105, 1451314530, doi:10.1029/1999jd901055, 2000.

Mason, S. A., Field, R. J., Yokelson, R. J., Kochivar, M. A., Tinsley, M. R., Ward, D. E., and Hao, W. M.: Complex effects arising in smoke plume simulations due to inclusion of direct emissions of oxygenated organic species from biomass combustion, J. Geophys. Res., 106, 12527-12539, doi:10.1029/2001jd900003, 2001.

McKeen, S. A., Wotawa, G., Parrish, D. D., Holloway, J. S., Buhr, M. P., Hübler, G., Fehsenfeld, F. C., and Meagher, J. F.: Ozone production from Canadian wildfires during June and July of 1995, J. Geophys. Res., 107, 4192, doi:10.1029/2001jd000697, 2002.

Miranda, A. I., Marchi, E., Ferretti, M., and Millán, M. M.: Forest Fires and Air Quality Issues in Southern Europe, in: Developments in Environmental Science, 8, edited by: Bytnerowicz, A., Arbaugh, M., Riebau, A., and Andersen, C., Elsevier B.V. 209231, 2009.

Nassar, R., Logan, J. A., Megretskaia, I. A., Murray, L. T., Zhang, L., and Jones, D. B. A.: Analysis of tropical tropospheric ozone, carbon monoxide, and water vapor during the 2006 El Niño using TES observations and the GEOS-Chem model, J. Geophys. Res., 114, D17304, doi:10.1029/2009JD011760, 2009.

Oltmans, S. J., Lefohn, A. S., Harris, J. M., Tarasick, D. W., Thompson, A. M., Wernli, H., Johnson, B. J., Novelli, P. C., Montzka, S. A., Ray, J. D., Patrick, L. C., Sweeney, C., Jefferson, A., Dann, T., Davies, J., Shapiro, M., and Holben, B. N.: Enhanced ozone over western North America from biomass burning in Eurasia during April 2008 as seen in surface and profile observations, Atmos. Environ., 44, 4497-4509, 2010.
Paris, J.-D., Stohl, A., Nédélec, P., Arshinov, M. Yu., Panchenko, M. V., Shmargunov, V. P., Law, K. S., Belan, B. D., and Ciais, P.: Wildfire smoke in the Siberian Arctic in summer: source characterization and plume evolution from airborne measurements, Atmos. Chem. Phys., 9, 9315-9327, doi:10.5194/acp-9-9315-2009, 2009.

Passant, N. R.: Speciation of UK emissions of non-methane volatile organic compounds, AEAT/ENV/R/0545 report, London, UK, 2002.

Pfister, G. G., Wiedinmyer, C., and Emmons, L. K.: Impacts of the fall 2007 California wildfires on surface ozone: Integrating local observations with global model simulations, Geophys. Res. Lett., 35, L19814, doi:10.1029/2008gl034747, 2008.

Phadnis, M. J. and Carmichael, G. R.: Forest fire in the boreal region of China and its impact on the photochemical oxidant cycle of East Asia, Atmos. Environ., 34, 483-498, 2000.

Poupkou, A., Giannaros, T., Markakis, K., Kioutsioukis, I., Curci, G., Melas, D., and Zerefos, C.: A model for European Biogenic Volatile Organic Compound emissions: Software development and first validation, Environ. Modell. Softw., 25, 1845-1856, 2010.

Real, E., Law, K. S., Weinzierl, B., Fiebig, M., Petzold, A., Wild, O., Methven, J., Arnold, S., Stohl, A., Huntrieser, H., Roiger, A., Schlager, H., Stewart, D., Avery, M., Sachse, G., Browell, E., Ferrare, R., and Blake, D.: Processes influencing ozone levels in Alaskan forest fire plumes during long-range transport over the North Atlantic, J. Geophys. Res., 112, D10S41, doi:10.1029/2006JD007576, 2007.

Saarikoski, S., Sillanpää, M., Sofiev, M., Timonen, H., Saarnio, K., Teinilä, K., Karppinen, A., Kukkonen, J., and Hillamo, R.: Chemical composition of aerosols during a major biomass burning episode over northern Europe in spring 2006: experimental and modelling assessments, Atmos. Environ., 41, 3577-3589, 2007.

Schultz, P.: An explicit cloud physics parameterization for operational numerical weather prediction, Mon. Weather Rev., 123, 3331-3343, 1995.

Sillmann, S.: The relation between ozone, $\mathrm{NO}_{\mathrm{x}}$ and hydrocarbons in urban and polluted rural environments, Atmos. Environ., 33, 1821-1845, 1999.

Simpson, D., Winiwarter, W., Borjesson, G., Cinderby, S., Ferreiro, A., Guenther, A., Hewitt, C. N., Janson, R., Khalil, M. A. K., Owen, S., Pierce, T. E., Puxbaum, H., Shearer, M., Skiba, U., Steinbrecher, R., Tarrason, L., and Öquist, M. G.: Inventorying emissions from nature in Europe, J. Geophys. Res., 104, 81138152, 1999.

Singh, H. B., Anderson, B. E., Brune, W. H., Cai, C., Cohen, R. C., Crawford, J. H., Cubison, M. J., Czech, E. P., Emmons, L., Fuelberg, H. E., Huey, G., Jacob, D. J., Jimenez, J. L., Kaduwela, A., Kondo, Y., Mao, J., Olson, J. R., Sachse, G. W., Vay, S. A., Weinheimer, A., Wennberg, P. O., and Wisthaler, A.: Pollution influences on atmospheric composition and chemistry at high northern latitudes: boreal and California forest fire emissions, Atmos. Environ., 44, 4553-4564, 2010.

Sofiev, M., Vankevich, R., Lotjonen, M., Prank, M., Petukhov, V., Ermakova, T., Koskinen, J., and Kukkonen, J.: An operational system for the assimilation of the satellite information on wildland fires for the needs of air quality modelling and forecasting, Atmos. Chem. Phys., 9, 6833-6847, doi:10.5194/acp-9-6833- 
2009, 2009.

Stein, U. and Alpert, P.: Factor Separation in Numerical Simulations, J. Atmos. Sci., 50, 2107-2115, doi:10.1175/15200469(1993)050<2107:FSINS > 2.0.CO;2, 1993.

Steinbrecher, R., Smiatek, G., Köble, R., Seufert, G., Theloke, J., Hauff, K., Ciccioli, P., Vautard, R., and Curci, G.: Intra- and inter-annual variability of VOC emissions from natural and seminatural vegetation in Europe and neighbouring countries, Atmos. Environ., 43, 1380-1391, 2009.

Stohl, A., Berg, T., Burkhart, J. F., Fjæraa, A. M., Forster, C., Herber, A., Hov, Ø., Lunder, C., McMillan, W. W., Oltmans, S., Shiobara, M., Simpson, D., Solberg, S., Stebel, K., Ström, J., Tørseth, K., Treffeisen, R., Virkkunen, K., and Yttri, K. E.: Arctic smoke - record high air pollution levels in the European Arctic due to agricultural fires in Eastern Europe in spring 2006, Atmos. Chem. Phys., 7, 511-534, doi:10.5194/acp-7-511-2007, 2007.

Tao, Z., Larson, S. M., Williams, A., Caughey, M., and Wuebbles, D. J.: Area, mobile, and point source contributions to ground level ozone: a summer simulation across the continental USA, Atmos. Environ., 39, 1869-1877, doi:10.1016/j.atmosenv.2004.12.001, 2005.

Tarasova, O. A., Brenninkmeijer, C. A. M., Jöckel, P., Zvyagintsev, A. M., and Kuznetsov, G. I.: A climatology of surface ozone in the extra tropics: cluster analysis of observations and model results, Atmos. Chem. Phys., 7, 6099-6117, doi:10.5194/acp-76099-2007, 2007.

Tzanis, C., Tsivola, E., Efstathiou, M., and Varotsos, C.: Forest fires pollution impact on the solar UV irradiance at the ground, Fresen. Environ. Bull., 18, 2151-2158, 2009.

Treffeisen, R., Tunved, P., Ström, J., Herber, A., Bareiss, J., Helbig, A., Stone, R. S., Hoyningen-Huene, W., Krejci, R., Stohl, A., and Neuber, R.: Arctic smoke - aerosol characteristics during a record smoke event in the European Arctic and its radiative impact, Atmos. Chem. Phys., 7, 3035-3053, doi:10.5194/acp-73035-2007, 2007.
Trentmann, J., Andreae, M. O., and Graf, H.-F.: Chemical processes in a young biomass-burning plume, J. Geophys. Res., 108, 4705, doi:10.1029/2003jd003732, 2003.

Ulevicius, V., Byčenkienè, S., Remeikis, V., Garbaras, A., Kecorius, S., Andriejauskiene, J., Jasinevičiene, D., and Mocnik, G.: Characterization of pollution events in the East Baltic region affected by regional biomass fire emissions, Atmos. Res., 98, 190-200, 2010 .

von Kuhlmann, R., Lawrence, M. G., Pöschl, U., and Crutzen, P. J.: Sensitivities in global scale modeling of isoprene, Atmos. Chem. Phys., 4, 1-17, doi:10.5194/acp-4-1-2004, 2004.

Verma, S., Worden, J., Pierce, B., Jones, D. B. A., Al-Saadi, J., Boersma, F., Bowman, K., Eldering, A., Fisher, B., Jourdain, L., Kulawik, S., and Worden, H.: Ozone production in boreal fire smoke plumes using observations from the Tropospheric Emission Spectrometer and the Ozone Monitoring Instrument, J. Geophys. Res., 114, D02303, doi:10.1029/2008JD010108, 2009.

Westerling, A. L., Hidalgo, H. G., Cayan, D. R., and Swetnam, T. W.: Warming and Earlier Spring Increase Western U.S. Forest Wildfire Activity, Science, 313, 940-943, 10.1126/science.1128834, 2006.

Wotawa, G. and Trainer, M.: The Influence of Canadian Forest Fires on Pollutant Concentrations in the United States, Science, 288, 324-328, doi:10.1126/science.288.5464.324, 2000.

Yokelson, R. J., Bertschi, I. T., Christian, T. J., Hobbs, P. V., Ward, D. E., and Hao, W. M.: Trace gas measurements in nascent, aged, and cloud-processed smoke from African savanna fires by airborne Fourier transform infrared spectroscopy (AFTIR), J. Geophys. Res., 108, 8478, doi:10.1029/2002jd002322, 2003.

Zare, A., Christensen, J. H., Irannejad, P., and Brandt, J.: Evaluation of two isoprene emission models for use in a longrange air pollution model, Atmos. Chem. Phys., 12, 7399-7412, doi:10.5194/acp-12-7399-2012, 2012. 